Article

\title{
Fly-Ash Pollution Modulates Growth, Biochemical Attributes, Antioxidant Activity and Gene Expression in Pithecellobium Dulce (Roxb) Benth
}

\author{
Sami Ullah Qadir ${ }^{1}$, Vaseem Raja ${ }^{2,3}$, Weqar Ahmad Siddiqui ${ }^{1}$, Mahmooduzzafar ${ }^{2}$, \\ Elsayed F. Abd_Allah 4 (D), Abeer Hashem ${ }^{5,6}$, Pravej Alam ${ }^{7}$ and Parvaiz Ahmad 5,8,*(D) \\ 1 Analytical Research Laboratory Department of Applied Sciences and Humanities, Faculty of Engineering \\ and Technology Jamia Millia Islamia, New Delhi 110025, India; samiullahqadir@gmail.com (S.U.Q.); \\ wsiddiqui@jmi.ac.in (W.A.S.) \\ 2 Department of Botany, Jamia Hamdard University, New Delhi 110062, India; \\ wrajamp2009@gmail.com (V.R.); mahmooduzzafar01@gmail.com (M.) \\ 3 Department of Botany, Govt. College for Women, Baramulla 193101, Jammu and Kashmir, India \\ 4 Department of Plant Production, Faculty of Food \& Agricultural Sciences, King Saud University, \\ Riyadh 11451, Saudi Arabia; elsayed_22@yahoo.com \\ 5 Botany and Microbiology Department, College of Science, King Saudi University, \\ Riyadh 11451, Saudi Arabia; abeer.hashem@gmail.com \\ 6 Mycology and Plant Disease Survey Department, Plant Pathology Research Institute, ARC, Giza 12511, Egypt \\ 7 Department of Biology, College of Science and Humanities, Prince Sattam bin Abdulaziz University, \\ Alkharj 11942, Saudi Arabia; pravejalam93@gmail.com \\ 8 Department of Botany, S.P. College, Srinagar 190001, Jammu and Kashmir, India \\ * Correspondence: parvaizbot@yahoo.com; Tel.: +966-114675873
}

Received: 20 October 2019; Accepted: 6 November 2019; Published: 20 November 2019

check for updates

\begin{abstract}
This study investigates the effect of fly ash (FA) on the Pithecellobium dulce (Roxb) Benth. trees growing at three different locations. FA stress caused significant changes in different leaf attributes like sugar, protein contents, photosynthetic pigments, nitrate content and nitrate reductase activity in foliar tissues of plants growing at a highly contaminated site, as compared to a low-pollution site. Lower rates of stomatal conductance (SC) were observed in P. dulce leaves under fly ash stress conditions that drastically reduced net photosynthetic rate $\left(\mathrm{P}_{\mathrm{N}}\right)$; however, intercellular carbon dioxide concentration and stomatal index (SI) showed an increase under the same stress conditions. On the other hand, significant increase was also observed in the proline, sulphur and nitrogen contents. A significant increase in oxidative stress and, consequently, in antioxidant enzymes such as ascorbate peroxidase (APX), catalase (CAT), peroxidase (POD), and superoxidase dismutase (SOD) and Air pollution tolerance index were discovered at three different sites. The transcriptional expression of antioxidant and stress responsive genes was higher at HPS as compared to two other two sites of the study. Taken together the results demonstrated that the $P$. dulce is best suited as a fly ash stress tolerant plant species with the potential to provide an alternative for the reclamation of fly ash affected soils.
\end{abstract}

Keywords: coal combustion; fly ash; oxidative stress; antioxidant enzymes; air pollution tolerance index

\section{Introduction}

Fly ash or flue ash (FA) is the coal combustion residue composed of fine particles of burned fuel, produced in bulk amounts from thermal power plants. Globally, FA generation from the thermal power plants is expected to increase to the amount of approximately 300-600 million tons per annum by the year 2020 [1], which may cover up to $3235 \mathrm{~km}^{2}$ of land area for its disposal [1], while FA production in 
India is likely to be $300-400$ million tons per annum by this period. FA generated from thermal power plants is disposed of either by wet or by dry methods. In case of dry disposal methods, FA is directly discarded in fly ash basins and landfills, while in the case of wet disposal methods, FA is often eroded out with water and piped as slurry into settling ponds, lagoons or artificial dams. Over the time, water from these settling ponds is permitted to channel away, and the ash left behind is often characterized as pond ash. Both of the disposal methods effectually encourage FA dumping of in landfills on open land. As a result, FA deposits exert harmful effects on the neighboring aquatic, terrestrial and aerial bionetworks. Fly ash disposal as the landfill is under compression from environmental disquiets and progressively rigorous environmental regulations are steadily ballooning the disposal costs [2]. In this direction, negligence toward FA dumps may lead to contamination of the environment to such an extent that may be alarming for both human health and day to day living [3,4]. In addition to toxic heavy metals such as polycyclic aromatic hydrocarbons (PAHs), $\mathrm{Cr}, \mathrm{Cd}, \mathrm{As}, \mathrm{Hg}, \mathrm{Pb}$, etc, are the chief pollutants of fly ash that lead to the contamination of soil, air, and water resources in the surrounding areas of coal-based thermal power plants. More often these pollutants become the serious threat for the adjacent vegetation [4-8]. Fly ash lagoons pose serious threats to human life by virtue of their ability to cause various skin, cardiac, genetic and respiratory problems and cancer [9].

All of the ecological problems arising due to disposal and management of FA can be diminished by the plantation of ash dumpsites. For the successful reinstatement of FA lagoons, analysis of adaptability and rejuvenation potential of plants in the FA ecosystem is desirable. Factually the hostile substrate and local environments are the strategic factors that hamper natural plant colonization on FA dumps [10]. Appropriate phytoremediating plant species should be planted to increase the potential of phyto-colonization on these FA dumpsites [11-13]. Among the key factors, that hamper plant growth and survival on FA dumping sites are deficiency of essential plant nutrients, mostly high boron content, available phosphorus $(0.05-0.2 \%)$ and nitrogen $(<0.05)$ [14]. Plantation checks erosion of FA and controls the leaching of noxious elements, either through binding of ash particles by their roots or by plant uptake [15]. Rigorous and unremitting deposition of contaminants on leaves of plants can cause several physiological disorders, decline in plant cover and, above all can lead to the vanishing of fragile species from the pollution-exposed sites.

Higher levels of these pollutants become phytotoxic and are often accompanied with reactive oxygen species (ROS) production. Pollutant-induced oxidative damage with overproduction of ROS in the form of superoxide radicals $\left(\mathrm{O}_{2}^{-}\right)$, hydroxyl radicals $\left(\mathrm{OH}^{-}\right)$, and hydrogen peroxide $\left(\mathrm{H}_{2} \mathrm{O}_{2}\right)$, which can rapidly interact with proteins, lipids, and DNA, may result in cell death [16-18]. Regardless of their damaging activity, ROS are deliberated to act as the second messenger actively involved in several signaling processes [19]. Plants respond to environmental insults by changing their biochemical, physiological and transcriptomic levels to the promising level. By the use of this composite machinery, plants may avert the damage and safeguard survival under harsh conditions [20], but often at the cost of condensed growth and productivity [21].

Thus, biostabilization is considered to be an operative resolution against environmental pollution of FA dumpsites [22]. Numerous investigators have evaluated the FA-grown plant species for their bioaccumulation potential for heavy metal remediation of FA dumps $[9,23]$. There are a few reports in regard to natural vegetation on FA deposits across the world, but a lesser amount of information is available about the phytodiversity of these FA deposits [24]. Given the above, this study attempts to recognize the potential impact of FA stress on some physiological, morphological and biochemical features of $P$. dulce, a naturally growing tree species at the FA dumpsite of Badarpur Thermal Power Plant (BTPP) in Delhi, India. 


\section{Materials and Methods}

\subsection{Study Area and its Climate}

Delhi, the capital of India, is located in the subtropical belt between $28^{\circ} 12^{\prime}-28^{\circ} 53^{\prime}$ North and $76^{\circ} 50^{\prime}-77^{\circ} 23^{\prime}$ East, roughly $216 \mathrm{~m}$ above the sea level, with a topographical area of about $1483 \mathrm{sq} . \mathrm{km}$ (53\% rural, $47 \%$ urban). The climate of Delhi is a monsoon-influenced, humid subtropical type with scorching, moist summers and temperatures ranging regularly from $20^{\circ} \mathrm{C}$ to $41^{\circ} \mathrm{C}$. Monsoons in Delhi commence from the month of July and continue to September with a medium to heavy precipitation. The winters in Delhi are relatively cold with the temperature falling to as low as $7^{\circ} \mathrm{C}$ due to a cold wave from the Himalayan province.

\subsection{Study Site Selection}

Three experimental sites (I, II, and III) for the present study were selected at about 0.5, 5, and $17 \mathrm{~km}$, respectively, from the Jamia Millia Islamia (JMI), a central university, to BTPP, a fly ash dumping site, downstream of the wind direction, because of the frequent flow of winds in this particular direction predominantly in the monsoon months. Being an academic area JMI, site (I) was selected as the control site as it was free from any pollution-causing sources. Compared to the other two sites (II and III), data on air quality revealed significantly lower concentrations of pollutants. Soil quality observed at all the three study sites was found to be sandy loam with coarse texture. The $\mathrm{pH}$ values of soil observed during the present study ranged from 6.69 to 7.16 at three different experimental sites. The study area had noticeably wet and dry periods due to the seasonality of air pollution differences. For the present study, winter season (Oct-Feb) was selected because concentrations of pollutants tend to be at maximum during this particular period [25].

\subsection{Sampling of Plant Material}

At each sampling location, five trees of P. dulce (family Fabaceae) were marked and the age of all the trees was calculated on the measured tree parameters, the diameter at breast height ( $\mathrm{dbh}$ ), and the total tree height as in [26]. From each tree, five fully expanded healthy leaves were collected from the two upper twigs fully exposed to sunlight. Thus, 75 leaves collected from three different locations were used for this study.

\subsection{Measurement of $\mathrm{pH}$ and Suspended Particulate Matter (SPM)}

The leaf extract $\mathrm{pH}$ was measured by following the method of [1]. Slurry of leaf material was prepared by homogenizing $0.5 \mathrm{~g}$ of leaf material in $50 \mathrm{~mL}$ of deionized water. The homogenate was centrifuged for $5 \mathrm{~min}$ at $10,000 \times g$, and the $\mathrm{pH}$ was measured from the supernatant with the help of $\mathrm{pH}$ meter (Mettler-toledo S-20). While for the $\mathrm{pH}$ measurement of FA and soil a known amount of FA and soil was dissolved the in double distilled water, the suspension was agitated at regular intervals and $\mathrm{pH}$ was recorded [25]. SPM was determined through the use of a High Volume Air Sampler (Envirotech, Redwoodcity, CA, USA).

\subsection{Epidermal Studies}

Epidermal studies in the leaves of $P$. dulce plants were carried out according to Ghouse and Yunus [27]. For microscopic analysis leaves were cut in $2 \mathrm{~cm} \times 2$, rectangular pieces heated with $60 \%$ nitric acid until peels got separated, and thoroughly washed with double distilled water, using safranin as a coloring agent, the peels were mounted on glass slides using Canada balsam. The procedure of Salisbury [28] was used for the calculation of Stomatal index (S.I.). The peels were also observed under Scanning Electron Microscope, using the procedure described by [29]. 


\subsection{Photosynthesis and Photosynthetic Pigments}

Leaf area measurements were carried out according to Qadir, et al. [14] using Leaf Area Meter (SYSTRONICS, 211 India). Photosynthetic parameters like carbon dioxide assimilation rate, stomatal conductance and net photosynthetic rate $(\mathrm{P} n)$, were measured in the morning between 7:00 and 9:30 using IRGA (LI-COR, Lincoln, NE, USA). Photosynthetic pigments were carried out through DMSO extraction method of Hiscox and Israelstam [30]. Calculations of the values were carried out according to the formulae of Duxbury and Yentsch [31] and Maclachlan and Zalik [32].

\subsection{Nitrogen Assimilation Related Parameters}

Nitrate reductase activity (NR) in the leaf samples was performed according to Klepper et al. [33]. Nitrate measurements were performed by Grover, et al. [34]. Fresh leaves were collected from the study sites washed with deionized water and treated with a freshly prepared solution of $\mathrm{CuSO}_{4}-\mathrm{ZnSO}_{4}$, charcoal, $0.1 \mathrm{~N} \mathrm{NaOH}$, and hydrazine sulphate. Reaction was stopped by using chilled acetone, for color development NEDD and Sulphanilamide was added. Spectrophotomatric analysis of the chromophore at $540 \mathrm{~nm}$ was performed according to Evans and Nason [35]. A condensed amount of nitrogen in leaf samples was estimated by Lindner [36] method.

\subsection{Sugar, Sulphur, Proline, and Protein Contents}

Total soluble sugar content was projected according to Dey [37] method, using sulphuric acid, $5 \%$ phenolethyl alcohol, and absorbance of the solution was recorded at $485 \mathrm{~nm}$ after cooling to room temperature. Total amount of sulphur in leaf materials was estimated as per Chesnin and Yien [38]. The amount of free proline was evaluated using the ninhydrin method [39]. Total soluble protein measurements in fresh leaves were performed following the Bradford [40] method, $100 \mu \mathrm{L}$ crude protein extract was thoroughly mixed with $1 \mathrm{~mL}$ of freshly prepared Bradford solution and the absorbance was recorded at $595 \mathrm{~nm}$, using bovine serum albumin as standard.

\subsection{Air Pollution Tolerance Index (APTI)}

For assessing APTI, four parameters, viz. Ascorbic Acid, leaf extract $\mathrm{pH}, \mathrm{RWC}$, and total chlorophyll content from the plant material were calculated. AA content was measured according to Keller and Schwager [41] and RWC was determined as per Qadir and Siddiqui [42] by using the mathematical expression (1). Mathematical expression (2) was used to calculate APTI as proposed by Singh, et al. [43].

$$
R W C=\left[\frac{F W-D W}{T W-D W}\right] \times 100
$$

where, TW $=$ Turgid weight, DW = Dry weight FW = Fresh weight

$$
\mathrm{APTI}=\frac{[A A(T+P)+R]}{10}
$$

where, $\mathrm{R}=$ Relative water content of leaf $(\%), \mathrm{P}=\mathrm{pH}$ of the leaf extract, $\mathrm{AA}=$ Ascorbic acid content (mg/gm.), extract and $\mathrm{T}=$ Total chlorophyll (mg/gm.), RWC = Relative water content.

\subsection{Estimation of Malondialdehyde (MDA) and Antioxidant Enzyme Activities}

MDA content from the leaf samples was measured as described by Heath and Packer [44]. For antioxidant assays, fresh leaves were selected randomly and mixed. $0.5 \mathrm{~g}$ freshly collected leaf material was macerated in $7 \mathrm{~mL}$ of $50 \mathrm{mM}$ phosphate buffer ( $\mathrm{pH} 7.8$ ) in pre-chilled pestle and mortar containing $1 \%$ polyvinyl pyrrolidine (PVP) and $1 \mathrm{mM}$ EDTA at $4{ }^{\circ} \mathrm{C}$ and centrifuged at $12,000 \times g$ for $40 \mathrm{~min}$ at $4{ }^{\circ} \mathrm{C}$ and the resulting upper layer was carefully aspirated and collected in pre-cooled fresh eppendorf tubes to determine different enzyme activities. 


\subsection{Ascorbate Peroxidase (APX EC1.11.1.11)}

APX activity was assessed as per Nakano and Asada [45] method. Reaction mixture consisted of $3 \mathrm{~mL}$ enzyme extract $(100 \mu \mathrm{L}), 0.3 \mathrm{mM}$ ascorbic acid, $100 \mathrm{mM}$ phosphate ( $\mathrm{pH} 7.0), 0.06 \mathrm{mM} \mathrm{H}_{2} \mathrm{O}_{2}$ and $0.1 \mathrm{mM}$ EDTANa 2 . The variation in absorption was noted at $290 \mathrm{~nm}$ after the addition of $\mathrm{H}_{2} \mathrm{O}_{2}$ for $2 \mathrm{~min}$ at every $30 \mathrm{~s}$ interval.

\subsection{Catalase (CAT, EC1.11.1.6)}

CAT activity was determined according to the method of Aebi [46] by observing $\mathrm{H}_{2} \mathrm{O}_{2}$ decomposition for $2 \mathrm{~min}$ at $240 \mathrm{~nm}$ using spectrophotometer (UV-2600 SHIMADZU, Kyoto, Japan). Reaction mixture $(3 \mathrm{~mL}$ ) consisted of $100 \mu \mathrm{L}$ enzyme extract, $50 \mathrm{mM}$ phosphate buffer ( $\mathrm{pH} 7.0), 2 \mathrm{mM}$ EDTA $\mathrm{Na}_{2}$ and $10 \mathrm{mM} \mathrm{H}_{2} \mathrm{O}_{2}$.

\subsection{Superoxide Dismutase (SOD, EC1.15.1.1)}

SOD enzyme activity was performed according to the method of Zhang, et al. [47]. Reaction mixture $(3 \mathrm{~mL})$ was prepared by dissolving $100 \mu \mathrm{L}$ of enzyme, $1.5 \mathrm{~mL}$ of $100 \mathrm{mM}$ phosphate buffer (pH 7.8), $75 \mu \mathrm{M}$ NBT, $0.2 \mathrm{~mL}$ of $10 \mathrm{mM}$ methionine, $0.1 \mathrm{~mL}$ of $50 \mu \mathrm{M}$ riboflavin and $0.1 \mathrm{mM}$ EDTA. The tubes containing the reaction mixture were placed under florescent light for about $20 \mathrm{~min}$ before the absorbance was measured at $560 \mathrm{~nm}$.

\subsection{Peroxidase (POD, EC1.11.1.7)}

POD activity was performed by following Zhou and Leul [48] method. Reaction mixture ( $3 \mathrm{~mL})$ consisted of enzyme extract $(100 \mu \mathrm{L}), 1.5 \mathrm{~mL}$ of $100 \mathrm{mM}$ phosphate buffer (pH 7.0), $0.4 \% \mathrm{H}_{2} \mathrm{O}_{2}$ and $1 \%$ guaiacol. The absorbance was determined at $470 \mathrm{~nm}$. The increase in absorbance caused due to guaiacol oxidation was estimated at every $1 \mathrm{~min}$ interval for $4 \mathrm{~min}$.

\subsection{Expression Analysis of Antioxidant and Stress Responsive Genes}

\subsubsection{Primer Design}

Primers corresponding to antioxidant and stress related genes were designed on the basis of gene sequences. Primer sequences and target genes are listed here, Ascorbate Peroxidase (APX): Forward 5' TTC GAT GGG TTG TGA TTT GA 3', Reverse 5' CGT TGC GTT AGA CTT GTT TT 3'; Superoxide Dismutase (SOD): Forward 5' ACT ATC TTC TTC ACC CAG GA 3', Reverse 5' GAG TTT GGT CCA GTA AGA GG 3'; Peroxidase (POD): Forward 5' CCG AAG CAT GAT TGG AGC AC 3', Reverse 5' AGC GCA GCA TCC GAA TCT AT 3'; Catalase (CAT): Forward 5' AAC CAT GAG GGA TAT TCG TG 3', Reverse $5^{\prime}$ TGG ATG TTA GTT TTC GGG TT 3'; Late Embyrogenisis abundant Proteins (LEA): Forward 5' GGA AGC ATG AAG CCGGA 3', Reverse 5' AGT CGA GGT CCC AAT CCG TA 3'; Dehydration Responsive Element binding factor (DREB): Forward 5' TGG CGT TAG GGT TTT CCG AT 3', Reverse 5' GCG GGT GCT TTT CGA GTT TT 3'; Tubulin (TB): Forward 5' GAT AAC TGT ACT GGA CTG CAAGG 3', Reverse 5' GGA TGG CTT CGT TAT CCA AGAG 3'. Software Primer 3 was used for primer selection and were prepared commercially (Integrated DNA Technologies IDT, Coral ville, IA, USA). Tubulin gene which served as an internal control was also amplified along with other genes.

\subsubsection{RNA Extraction and Semi-Quantitative PCR Analysis}

RNA from fresh leaves was extracted by using Trizol reagent (Thermo Scientific, Weltham, MA, USA). The Purification was carried out by passing the RNA through on-column DNaseI and RNAeasy spin column. Eluted RNA was quantified spectrophotometrically and the quality was analyzed through agarose gel electrophoresis. cDNA synthesis was performed by using RevertAid cDNA synthesis kit (Thermo Fisher Scientific) according to the supplier's instructions. PCR reaction was 
carried out in a final reaction mixture of $50 \mu \mathrm{L}$ containing $1 \mu \mathrm{L}$ of cDNA, $0.1 \mathrm{mM}$ dNTPs, $1 \mathrm{X}$ PCR buffer, 0.5 unit of Taq DNA polymerase (Sigma-Aldrich), $1 \mu \mathrm{M}$ primer (each reverse and forward) and nuclease free water. Amplification was carried out with thermal cycler (Veriti-96 Applied Biosystems) using following condition $2 \mathrm{~min}$ at $95^{\circ} \mathrm{C}$ and then 35 cycles for $32 \mathrm{~s}$ each at $95^{\circ} \mathrm{C}, 35 \mathrm{~s}$ at $54-57$ (annealing temprature optimized for each gene), and $40 \mathrm{~s}$ for $72{ }^{\circ} \mathrm{C}$ followed by a final step of $10 \mathrm{~min}$ at $72{ }^{\circ} \mathrm{C}$. PCR amplification products were subjected to gel electrophoresis, stained with ETBR, and visualized under UV light, gels were scanned in the Gel Documentation System (Kodak, Rochester, NY, USA).

\subsubsection{Quantitative Real-Time PCR}

Quantitative real-time qPCR was carried out with the help of ABI 7300 RT-PCR system (Applied Biosystems) with PowerUP ${ }^{\mathrm{TM}}$ SYBR Green Master Mix. Amplification of antioxidant and stress related genes ( $A P X, S O D, P O D, C A T, L E A$, and DREB) was achieved as per manufacturer's protocol. PCR reaction of about of $20 \mu \mathrm{L}$ consisted $12.5 \mu \mathrm{L}$ of $2 X$ PowerUP $^{\text {TM }}$ SYBR Green Master Mix, $10 \mathrm{ng}$ of cDNA template, $300 \mathrm{nM}$ primer (reverse and forward), and nuclease free water. The following conditions were used for thermocycling: $2 \mathrm{~min}$ at $50{ }^{\circ} \mathrm{C}, 10 \mathrm{~min}$ at $95^{\circ} \mathrm{C}$ and 40 cycles alternating between $15 \mathrm{~s}$ at $95^{\circ} \mathrm{C}$ and $1 \mathrm{~min}$ at $60^{\circ} \mathrm{C}$ to verify primer specificity melting curve analysis $\left(65-95^{\circ} \mathrm{C}\right)$ was routinely performed after 40 cycles. A single amplified product for all genes was observed from the melting curves. For each sample three analytical replicates were used for the calculation of expression levels of the individual genes along with tubulin as an internal control and recorded as $\mathrm{Ct}$ at the default threshold (0.2). $C t$ was transformed to quantities relative to the sample and $C t$ values of the used target genes were normalized using the $C t$ values of tubulin, mRNA levels of the genes were normalized with that of the tubulin [49]. $2^{-\Delta \Delta C t}$ method [50] was used for the calculation of relative expression levels of the genes in respect to that of control.

\subsection{Statistical Analysis}

Experiments were conducted in five replications. Data was analyzed using IBM SPSS statistics 16.0 software and were articulated as mean \pm SD. ANOVA with Duncan's multiple range test as a post-hoc test $(P<0.05)$ was applied to calculate significant differences between three sites.

\section{Results and Discussion}

Suspended particulate matter (SPM) was monitored weekly in various localities of Delhi, data indicating that the JMI site (I), i.e., low pollution site (LPS) was least charged with SPM as the lowest mean value recorded for the SPM was $\left(209.08 \pm 19.68 \mu \mathrm{g} \mathrm{m}^{-3}\right)$ followed by site (II) of medium pollution (MPS) with average SPM concentration of $\left(221.34 \pm 33.33 \mu \mathrm{g} \mathrm{m}^{-3}\right)$, while the dumping site of BTPP site (III) was the high pollution site (HPS), showing very high SPM levels of $\left(254.98 \pm 62.50 \mu \mathrm{g} \mathrm{m}^{-3}\right)$. Generally, the load of pollution depends on the levels of emission sources, and micrometeorological factors [51,52]. During the present study it was observed that site III was most polluted possibly due to significantly higher FA concentration because of open dumping of FA, together with other pollutants released into the atmosphere. Contrary to this, JMI site (I), was protected by high boundary walls with good tree density, restricted vehicular traffic and no industrial activity in its vicinity.

Plants exposed to pollution experience numerous morphological, physiological, biochemical and ultrastructural changes upon prolonged exposure [51,53]. Table 1 reflects the values of leaf traits such as leaf width, length and SLA, of $P$. dulce growing at three different sites. With increasing pollution load all the leaf attributes showed a decreased trend. A significant variation was noticed among these plant characteristics (leaf width, $F=503.60, P<0.001$; leaf length, $F=128.77, P<0.001$; SLA, $F=246.83$, $P<0.001$ ), showing a variation of $51 \%, 45 \%$ and $66 \%$ between LPS and HPS, respectively.

Contrary to control site, dust load is considered to be an important factor responsible for the decline in leaf performance at the contaminated site [25]. They reported a reduction in the SLA in plant leaves growing at a highly industrial polluted area of Chunar, Mirzapur of India in comparison to that of low pollution area of the Banaras Hindu university campus. Similar results were reported in 
Azadirachta indica [14] under FA stress. Reductions in the leaf area might be attributed to decreased leaf production, and/or higher rates of senescence caused by the impact of cement dust pollution stress [54-56] on the photosynthesis capacity and cell elongation mechanism [57].

Table 1. Functional stomatal characteristics and Leaf attributes of $P$. dulce at three sites.

\begin{tabular}{|c|c|c|c|c|c|c|c|}
\hline Sites & $\begin{array}{c}\text { Intercellular } \\
\text { Carbon } \\
\text { Dioxide (mmol, } \\
\left.\mathrm{CO}_{2} \mathrm{~m}^{-2} \mathrm{~S}^{-1}\right)\end{array}$ & $\begin{array}{c}\text { Stomatal } \\
\text { Conductance } \\
\left(\mathrm{mmol}^{-} \mathrm{CO}_{2}\right. \\
\left.\mathrm{m}^{-2} \mathrm{~S}^{-1}\right)\end{array}$ & $\begin{array}{l}P_{N}(m m o l \\
\left.m^{-2} S^{-1}\right)\end{array}$ & $\begin{array}{l}\text { Stomatal } \\
\text { Index (\%) }\end{array}$ & SLA $\left(\mathrm{cm}^{2}\right)$ & $\begin{array}{l}\text { Leaf Length } \\
\text { (cm) }\end{array}$ & $\begin{array}{l}\text { Leaf Width } \\
\text { (cm) }\end{array}$ \\
\hline LPS & $313.22 \pm 24.70$ & $1.15 \pm 0.78$ & $5.36 \pm 1.62$ & $14.12 \pm 0.48$ & $6.31 \pm 0.85$ & $9.16 \pm 0.61$ & $3.56 \pm 0.26$ \\
\hline MPS & $331.38 \pm 25.93$ & $0.87 \pm 0.52$ & $4.47 \pm 1.60$ & $14.15 \pm 0.43$ & $4.23 \pm 0.21$ & $6.93 \pm 1.20$ & $2.59 \pm 0.25$ \\
\hline HPS & $353.80 \pm 26.11$ & $0.61 \pm 0.24$ & $3.36 \pm 1.76$ & $15.63 \pm 0.63$ & $3.06 \pm 0.23$ & $4.94 \pm 0.90$ & $1.21 \pm 0.27$ \\
\hline
\end{tabular}

Varying degrees of foliar necrosis and chlorosis observed at HPS indicate degradation of photosynthetic pigments in the leaf tissue. The site-specific variation in biochemical properties of $P$. dulce are presented in Figure 1a-d. The amount of Chlorophyll " $a$ " decreased with an increase in FA stress. It was $0.51 \mathrm{mg} \mathrm{g}^{-1}$ at LPS which declined to $0.47 \mathrm{mg} \mathrm{g}^{-1}(7.84 \%)$ at MPS and $0.32 \mathrm{mg} \mathrm{g}^{-1}$ $(37.25 \%)$ at HPS. In relation to the intensity of FA pollution considerable differences were also observed in Chlorophyll " $b$ ", total chlorophyll and carotenoids, in the foliar tissue of plants growing at different sites. Chlorophyll $b$ content was $0.33 \mathrm{mg} \mathrm{g}^{-1}$ at LPS, $0.32 \mathrm{mg} \mathrm{g}^{-1}$ at MPS and $0.22 \mathrm{mg} \mathrm{g}^{-1}$ at HPS, displaying a maximum decline of $35.30 \%$ at HPS, in comparison to LPS. Total chlorophyll and carotenoid contents also shows a declining trend from LPS to HPS, the maximum reduction being $37.64 \%$, and $43.58 \%$, respectively, as shown in Figure 1a. From ANOVA, significant variation in the plant pigments at three different sites was noticed (Chlorophyll $a, F=32.00, P<0.01$; Chlorophyll $b, F=19.11, P<0.01$; Carotenoids, $F=19.07, P<0.01$; total chlorophyll, $F=29.14, P<0.01)$.
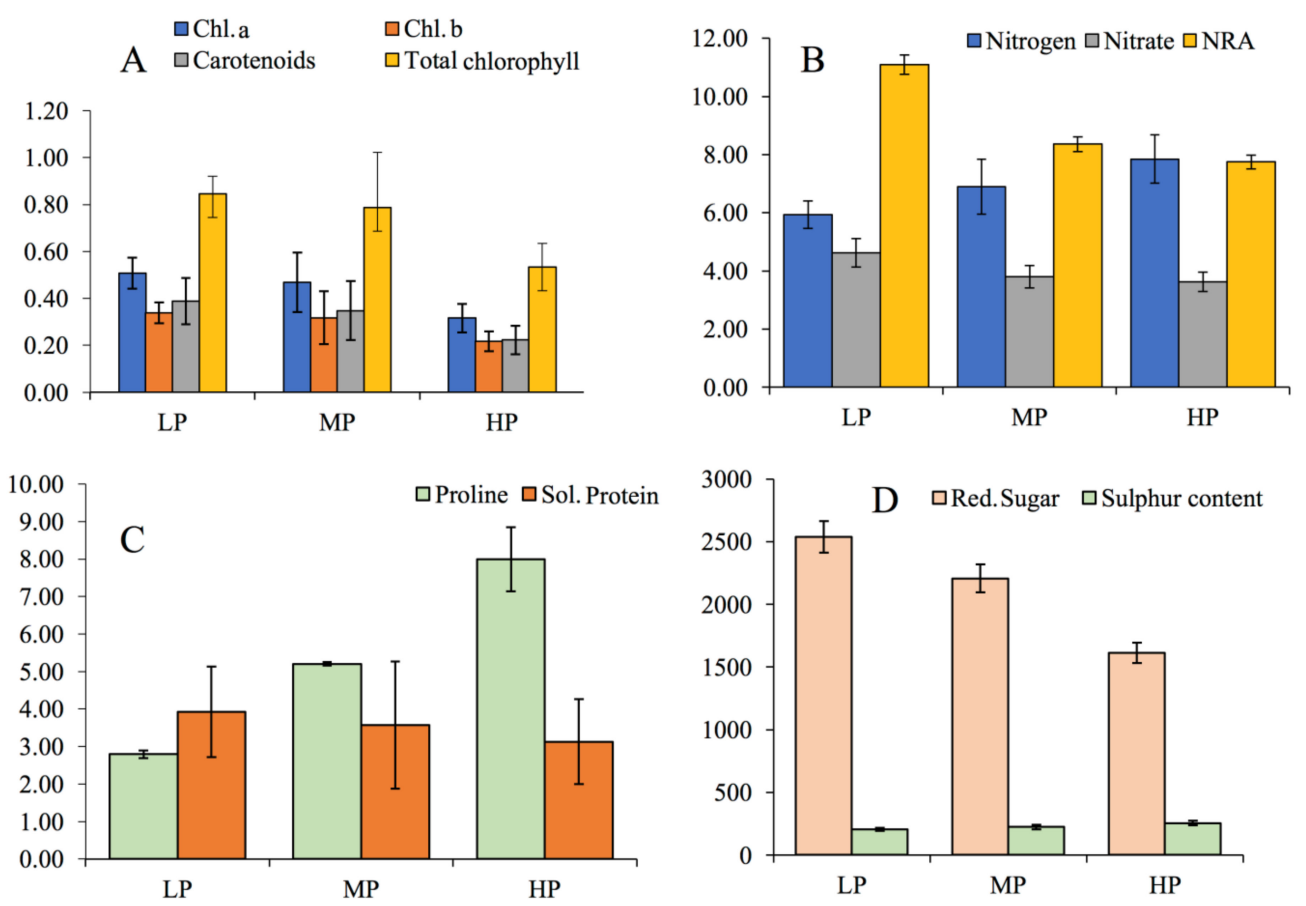

Figure 1. Variation in the biochemical parameters of $P$. dulce at three different sites (A) Chl. $A$, Chl. $b$, carotenoids, total chlorophyll $\left(\mathrm{mg} \mathrm{g}^{-1} \mathrm{fw}\right)\left(\right.$ B) Nitrate and NRA $\left(\mathrm{mmolg}^{-1} \mathrm{fw}\right)(\mathbf{C})$ protein $\left(\mathrm{mg} \mathrm{g}^{-1} \mathrm{fw}\right)$ and proline $\left(\mu \mathrm{g} \mathrm{g}^{-1} \mathrm{fw}\right)(\mathbf{D})$ Sulphur $\left(\mathrm{mg} \mathrm{g}^{-1} \mathrm{dw}\right)$ and reducing sugar $\left(\mathrm{mg} \mathrm{g}^{-1} \mathrm{fw}\right)$. Data represents mean $\pm \operatorname{SD}(n=5)$. 
Chlorophyll measurement under stressful environments is considered to be an imperative tool to assess the effects on plants because of its direct involvement in several metabolic processes. Any reduction in chlorophyll content has direct bearance on growth, productivity and tolerance $[52,58,59]$. Our study reports a significant reduction $(P<0.01)$ in plant pigments which may be associated with chloroplast damage by FA pollution stress. Reduction in pigment concentration of foliage surfaces may be attributed to the shading effect of FA particles at the polluted site than at the control [59]. FA particles might clog stomata, which leads to intensification in leaf temperature and interference with the gaseous exchange that may subsequently impede chlorophyll synthesis [25]. It is well documented that plants thriving in polluted environments often display alarming levels of photosynthetic pigments like chlorophyll " $a$ ", chlorophyll " $b$ " and total chlorophyll [60]. Pollution-induced photosynthetic pigment degradation was also documented in some recent studies $[53,59,61,62]$. Leaf surface crust formation of an alkaline nature is also deliberated to be one of the chief factors that contributed to the reduction in photosynthetic capacity under polluted environments [63]. It is assumed that at a site with maximum pollution load, chlorophyll " $a$ " is often degraded to pheophytin and the formation of Chlorophyllide " $b$ " occurs by the removal of phytol group from chlorophyll " $b$ " [62] which is no longer capable to harvest solar energy for photosynthesis thereby resulting in a decrease in the chlorophyll pigments [61].

Carotenoids are an assembly of fat-soluble natural pigments associated with the photosynthetic process in photosynthetic bacteria, algae and plants. Several workers have also reported the loss of carotenoid pigments due to the action of pollutants $[14,53,64]$. Carotenoids prevent photo-oxidation of chlorophyll by acting as an antioxidant, but this normal defensive process of carotenoids is vulnerable to environmental stress and often results in cellular devastation, including pigment dilapidation [64].

With the increase in pollution stress from LPS to HPS nitrogen content in leaves showed an increasing trend. Nitrogen content at LPS was $5.94 \mathrm{mmolg}^{-1}$ which increased to $6.90 \mathrm{mmolg}^{-1}(16.16 \%)$ at MPS and $7.85 \mathrm{mmolg}^{-1}(32.15 \%)$ at HPS. Maximum reduction of $21.42 \%$ and $30.14 \%$ between LPS and HPS were observed in the case of nitrate content and nitrate reductase activity respectively (Figure 1b). Significant variations among these parameters were observed at all study sites (nitrogen $F=38.22$, $P<0.01$; nitrate $F=41.98, P<0.01$; NRA, $F=4.51, P<0.05$ ). We found a significant positive relationship between FA stress and nitrogen content of plant leaves $(r=0.414, P<0.01)$. Values corresponding to correlation coefficient between sites and various morpho-physiological attributes, antioxidant enzymes and biochemical parameters showed a significant relationship, as given in Table 2. Several researchers have reported an upsurge in the foliar nitrogen content in plants under pollution-stressed environments $[14,25,53]$. Nitrate reductase is metalloflavo protein inducible enzyme that plays a key role in the assimilatory reduction of nitrate to ammonia using NADH as an electron donor. NR activity is severely affected by metals, drought and salinity stress. Since FA has a low water-retention capacity coupled with high $\mathrm{pH}$, therefore a decline in NRA of plants growing on raw fly ash might be due to low availability of substrate, salinity stress due to presence of salts, and an uptake of toxic metals from FA, which may exchange active metal sites of enzymes or generate active oxygen species that cause oxidation and cross-linking of SH groups [65]. The present study shows a strong negative relationship between sites and nitrate concentration of $P$. dulce $(r=-0.69, P<0.01)$. Pollution stress may negatively or positively affect foliar nitrate content. Fast-growing species often assimilate higher quantities of nitrates besides increased NR activities to put up an increased available soil nitrate. Similar results have been previously observed in Azadirachta indica [14,53].

Similar to pigment contents, a reduction in leaf protein content was also observed at polluted sites. During the present study, a maximum reduction of $20.36 \%$ in the case of leaf protein content was observed at HPS in comparison to LPS $(F=2.14, P>0.05)$. In the case of proline, significant increase $(F=678.92, P<0.01)$ was noticed from LPS to HPS, showing an increment of $185 \%$, as shown in Figure 1c. A significant negative relationship existed between sites and soluble protein $(r=-0.24$, $P<0.05$ ) (Table 3). Reduction in protein content in response to FA stress might be attributed to the breakdown of existing protein to amino acids, higher rates of protein denaturation and/ or reduced de 
novo protein synthesis [53,55]. From the collected data a positive correlation $(r=0.974 ; P<0.001)$ exists between FA stress and proline accumulation (Table 3). Proline accumulation could be the result of de nevo synthesis, lower utilization, and decreased degradation hydrolysis of proteins. As multifunctional amino acid proline seems to have diverse roles under stressful conditions such as stabilization of subcellular structures, membranes and proteins, besides acting as an outstanding osmolyte, also plays the role of a metal chelator and acts as an antioxidant molecule [66]. Several researchers have reported that elevated proline levels in plants under stressful environmental conditions could impart stress tolerance by sustaining osmotic stability or cell turgor and protect cellular functions by scavenging ROS, thus checking oxidative burst in plants. An increase in proline levels under stressful environments was also reported $[14,53,66]$.

Table 2. ANOVA Summary of APTI related parameters and antioxidant enzymes at three experimental sites of $P$. dulce.

\begin{tabular}{cccccc}
\hline Parameters & Sum of Squares & Df & Mean Square & F & Sig. \\
\hline Ascorbic acid & 23.32 & 74 & 11.66 & 54.76 & $* * *$ \\
pH & 32.35 & 74 & 16.18 & 441.83 & $* * *$ \\
FW & 3268.12 & 74 & 1634.06 & 8006.07 & $* * *$ \\
DW & 2768.57 & 74 & 1384.28 & 2976.34 & $* * *$ \\
TW & 4135.29 & 74 & 2067.65 & 2685.09 & $* * *$ \\
RWC & 71.17 & 74 & 35.58 & 0.27 & NS \\
APTI & 63.11 & 74 & 31.55 & 21.97 & $* * *$ \\
SOD & 694.25 & 74 & 347.13 & 961.79 & $* * *$ \\
APX & 93.39 & 74 & 46.70 & 6467.29 & $* * *$ \\
CAT & 377.16 & 74 & 188.58 & 3644.43 & $* * *$ \\
POD & 238.34 & 74 & 119.17 & 488.64 & $* * *$ \\
MDA & 25.20 & 74 & 12.60 & 2282.15 & $* * *$ \\
\hline
\end{tabular}

Foliar sugar content decreased significantly in the leaves of $P$. dulce under fly ash stress $(F=4.04$, $P<0.05)$. Foliar sugar content perceived at LPS was $2537.76 \mu \mathrm{g} \mathrm{g}^{-1}, 2206.82 \mu \mathrm{g} \mathrm{g}^{-1}$ at MPS and $1613.62 \mu \mathrm{g} \mathrm{g}^{-1}$ at HPS, signifying a reduction of $36.41 \%$ between LP and HPS (Figure $1 \mathrm{~d}$ ). Soluble sugar is an important reservoir of energy for almost every single living creature on this planet. Plant species produce this organic substance through several important processes like photosynthesis and during respiratory breakdown. During the present study a significant decline $(P<0.05)$ in soluble sugar content was observed in $P$. dulce under fly ash stress. Soluble sugars concentration governs the sensitivity of plants to FA stress and also point to the physiological activity of a plant. A decline in total soluble sugar content indicates the intervention of light absorption triggered by FA dust deposition over the surface of leaves. Similar reports of decreased sugar content of crops, chlorophyll degradation and decreased $\mathrm{CO}_{2}$ fixation, and increased respiration, due to cement dust was also reported by Tripathi and Gautam [67].

Plant foliar sulphur content increased significantly $(F=64.46, P<0.01)$ from LPS to HPS. The maximum sulphur content of $255.40 \mu \mathrm{molg}^{-1}$ was recorded at HPS, followed by MPS $\left(223.30 \mu \mathrm{molg}^{-1}\right)$, while the minimum $\left(204.59 \mu \mathrm{molg}^{-1}\right)$ was recorded at LPS, resulting in a difference of $53.96 \%$ between the LPS and HPS (Figure 1d). In plants leaf sulphur content at several developmental stages, is determined by the atmospheric as well as soil sulphur uptake by the plant. It has been demonstrated that plants exposed to $\mathrm{SO}_{2}$ accumulate sulphur mainly through open stomata on leaves present on aerial plant parts [53]. Constant upsurge in sulphur content in leaves of $P$. dulce indicates the magnitude of pollution load at the sites of highest pollution. This also points toward the letdown of the detoxification mechanism involved in the elimination of the surplus S-derived bisulphite and sulphite ions. A higher amount of sulphur beyond permissible limits has potential damaging effects on plants, chiefly under synergetic effects of other contaminants [14,52]. A significant increase in intercellular carbon dioxide $(F=14.78, P<0.01)$ and stomatal index $(F=68.83, P<0.01)$ was observed with an 
increase in fly ash stress. Intercellular $\mathrm{CO}_{2}$ concentration enhanced from LPS to site HPS, displaying a maximum enhancement of $12.95 \%$. However, at MPS, an increase of $5.77 \%$ was observed when compared to LPS. Stomatal conductance shows a significant $(F=5.79, P<0.001)$ decline of $46.95 \%$ between the control (LPS) and the highly polluted site. A significant decrease was also observed in the case of NPR $(F=9.10, P<0.01)$ under higher levels of FA contamination in the environment. In $P$. dulce, net photosynthetic rate $\left(\mathrm{P}_{\mathrm{N}}\right)$ showed a reduction of $16.60 \%$ and $37.31 \%$ between MPS and HPS. Stomatal index (SI) shows an augmentation of 10.69\% from LP to HPS, as shown in Table 1. In response to pollution, Stomatal index may either increase or decrease as an avoidance strategy or an adaptive trait. Stomatal appearance was indubitably affected by FA stress as manifested from the SEM images of epidermal surfaces (Figure 2).
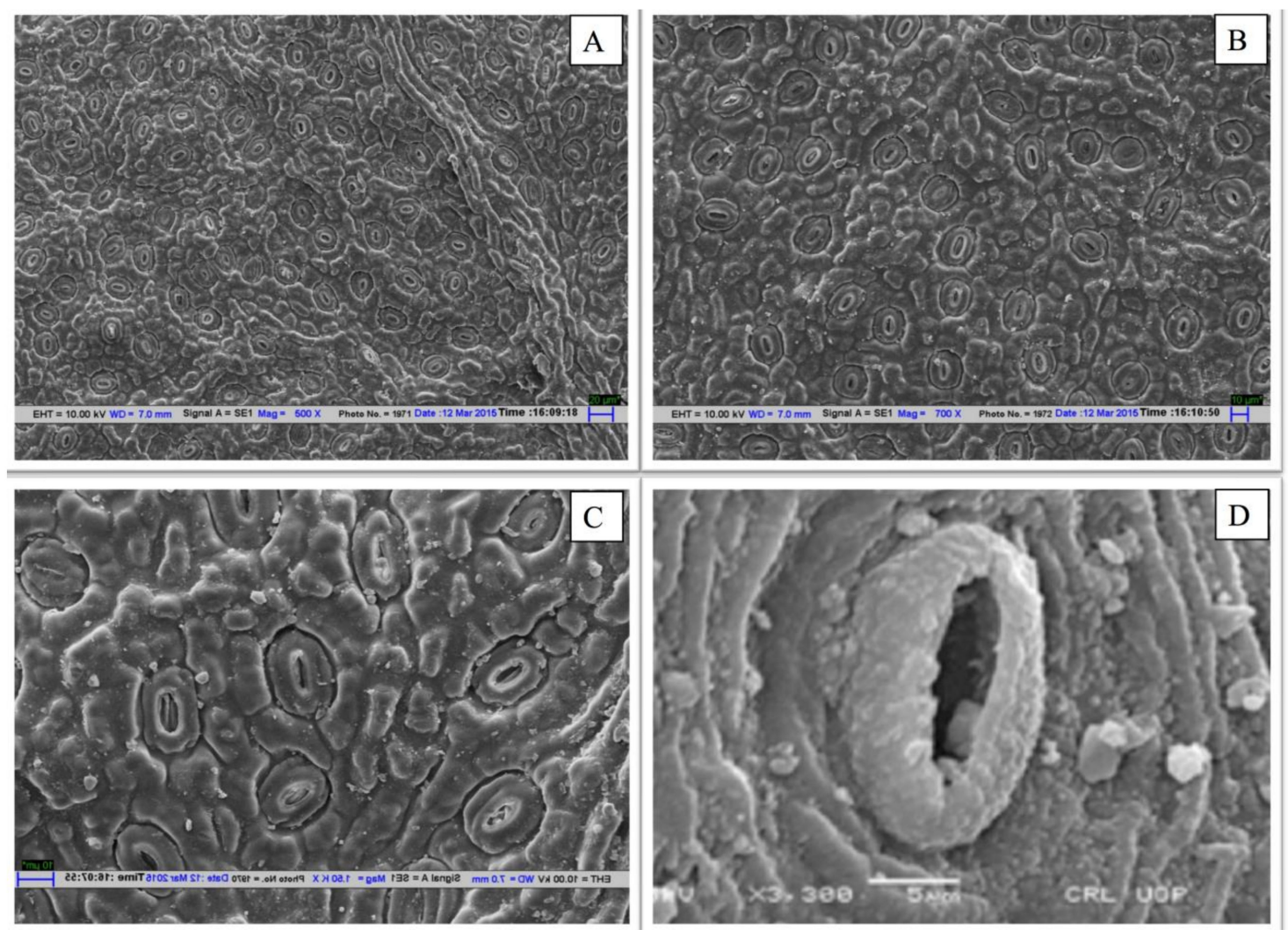

Figure 2. Leaf stomatal morphology of P. dulce as seen under SEM. (A\&B) collection from LPS showing normal stomatal morphology. (C\&D) collection from HPS showing stomata in deteriorated conditions with FA dust accumulation.

A decrease in the net photosynthetic rate led to elevated levels of intercellular carbon dioxide. A reduction in photosynthetic rate and stomatal conductance in tree species has been ascribed to dust load, as stated by Chaturvedi, et al. [25]. Any decrease in stomatal conductance under FA contamination may be ascribed to pore size reduction, high intercellular carbon dioxide concentration and lowered photosynthetic rate due to FA dust deposition (Figure 2). The noticeable decline in the stomatal index at the contaminated sites was similar to the findings with poplar clones, wherein SI condensed under raised $\mathrm{CO}_{2}$ level in the growing leaves [58]. 
Table 3. Correlation coefficients for linear regression between biochemical parameters, leaf attributes of $P$. dulce at three different sites.

\begin{tabular}{|c|c|c|c|c|c|c|c|c|c|c|c|c|c|c|c|c|c|c|c|c|c|c|c|c|c|c|c|c|c|c|c|c|}
\hline & $\begin{array}{l}\text { Sites } \\
1\end{array}$ & Chl. a & Chl. b & CTDS & T. Chl. & NPR & NRA & Nitrate & Nitrogen & $\begin{array}{l}\text { Proline } \\
\text { Pol }\end{array}$ & SPT & $\mathrm{RS}$ & $\mathrm{SCc}$ & SI & sc & ICD & SPM & SLA & $\mathrm{LL}$ & LW & $\mathrm{AA}$ & $\mathrm{pH}$ & $\mathrm{FW}$ & $\mathrm{DW}$ & $\mathrm{Tw}$ & RWC & APTI & SOD & APX & $\begin{array}{ll}\text { CAT } \\
\end{array}$ & POD & MDA \\
\hline $\begin{array}{l}\text { Sitses } \\
\text { Chl. a } \\
\text { Chl. b. }\end{array}$ & $-0.551^{a}$ & & & & & & & & & & & & & & & & & & & & & & & & & & & & & & & \\
\hline $\begin{array}{l}\text { CrDS } \\
\text { T.Chl. }\end{array}$ & $\begin{array}{l}-0.555^{a} \\
-0.0 .308\end{array}$ & $\begin{array}{l}0.288^{a} \\
0.077 a^{2}\end{array}$ & $\begin{array}{l}0.983^{a} \\
0.0512\end{array}$ & {$\left[\begin{array}{c}1 \\
0.889 \mathrm{ag}\end{array}\right.$} & & & & & & & & & & & & & & & & & & & & & & & & & & & & \\
\hline $\begin{array}{l}\text { NPR } \\
\text { NRA } \\
\text { Nits }\end{array}$ & $\begin{array}{c}-0.444^{a} \\
-0.314^{a} \\
-0.068\end{array}$ & $\begin{array}{l}0.6 .64^{2} \\
0.024^{2}\end{array}$ & $\begin{array}{l}0.6 .64^{a} \\
0.2925\end{array}$ & $\begin{array}{l}0.5512^{\mathrm{a}} \\
0.0557^{\mathrm{a}}\end{array}$ & 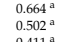 & $\begin{array}{c}1 \\
0.608 \\
\end{array}$ & 1 & & & & & & & & & & & & & & & & & & & & & & & & & \\
\hline 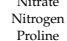 & 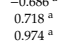 & 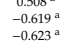 & 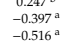 & $\begin{array}{c}-0.462^{a} \\
-0.0535\end{array}$ & 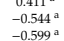 & $\begin{array}{l}-0.0357^{-0.3} \\
-0.381^{2}\end{array}$ & $\begin{array}{l}0.0699 \mathrm{a} \\
-0.619 \mathrm{a} \\
-0.02019\end{array}$ & $\begin{array}{c}-0.677^{\mathrm{a}} \\
-0.0623 \mathrm{a}\end{array}$ & 18 & & & & & & & & & & & & & & & & & & & & & & & \\
\hline $\begin{array}{c}\text { SPrT } \\
\text { rits }\end{array}$ & $\begin{array}{l}-0.2796^{\mathrm{b}} \\
-0.033^{2}\end{array}$ & $\begin{array}{l}0.072 \mathrm{a} \\
0.632)^{2}\end{array}$ & 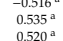 & $\begin{array}{l}0.5033^{\mathrm{a}} \\
0.3790^{2}\end{array}$ & $\begin{array}{l}-0.599^{\circ} \\
0.0420^{\circ}\end{array}$ & $\begin{array}{l}0.700^{\mathrm{a}} \\
0.760^{2}\end{array}$ & $\begin{array}{l}-0.211^{\circ} \\
0.768^{\circ} \\
0.085\end{array}$ & 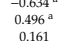 & $\begin{array}{l}0.0 .038^{a} \\
0.014 a^{2}\end{array}$ & $\begin{array}{c}-1.192 \\
-0.268 \mathrm{~b}\end{array}$ & $\begin{array}{l}1 \\
0.48 \mathrm{a}\end{array}$ & & & & & & & & & & & & & & & & & & & & & \\
\hline $\begin{array}{l}\text { Scc. } \\
\text { Sc. }\end{array}$ & $\begin{array}{l}0.792^{a} \\
0.017 a^{2}\end{array}$ & $\begin{array}{l}-0.496^{a} \\
-0.720^{2}\end{array}$ & $\begin{array}{l}-0.578 \mathrm{a} \\
-0.477 \mathrm{a}\end{array}$ & $\begin{array}{l}-0.552^{a} \\
-0.543^{2}\end{array}$ & $\begin{array}{l}-0.555^{\mathrm{a}} \\
-0.0 .699^{2}\end{array}$ & $\begin{array}{l}-0.034^{a} \\
-0.40^{2}\end{array}$ & $\begin{array}{c}0.093 \\
-0.510^{a}\end{array}$ & $\begin{array}{l}-0.248 \mathrm{~b} \\
-0.527\end{array}$ & $\begin{array}{l}0.331^{a} \\
0.725^{a}\end{array}$ & 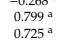 & $\begin{array}{l}-0.077 \\
-0.0272 \\
-0.23^{2}\end{array}$ & $\begin{array}{l}-0.499 a^{-0.09} \\
-0.067\end{array}$ & $0.493^{\circ a}$ & & & & & & & & & & & & & & & & & & & \\
\hline $\begin{array}{l}\mathrm{SC} \\
\mathrm{ICD}\end{array}$ & $\begin{array}{l}-0.377^{\mathrm{a}} \\
0.055 \mathrm{a}^{2}\end{array}$ & $\begin{array}{c}0.7377^{\mathrm{a}} \\
-0.226^{2}\end{array}$ & $\begin{array}{c}0.681^{\mathrm{a}} \\
-0.220^{2}\end{array}$ & $\begin{array}{l}0.865^{2} \\
0.004\end{array}$ & $\begin{array}{c}0.740^{a} \\
-0.269^{6}\end{array}$ & $\begin{array}{c}0.500^{\mathrm{a}} \\
-0.472^{2}\end{array}$ & $\begin{array}{l}0.557 \mathrm{a} \\
-0.046\end{array}$ & $\begin{array}{c}0.188 \\
-0.0699^{2}\end{array}$ & $\begin{array}{l}-0.400^{a} \\
0.723^{b}\end{array}$ & $\begin{array}{l}-0.3511^{a} \\
0.444^{a}\end{array}$ & $\begin{array}{l}0.5959 \mathrm{~s} \\
-0.114\end{array}$ & $\begin{array}{c}0.278^{\mathrm{b}} \\
-0.0880^{2}\end{array}$ & $\begin{array}{l}-0.9292^{\mathrm{b}} \\
0.404 \mathrm{a}^{\mathrm{a}}\end{array}$ & $\begin{array}{c}-0.427^{\mathrm{a}} \\
0.2020^{\mathrm{a}}\end{array}$ & $\begin{array}{c}1 \\
0.227^{\mathrm{b}}\end{array}$ & & & & & & & & & & & & & & & & & \\
\hline $\begin{array}{l}\text { SPM } \\
\text { SLA }\end{array}$ & $\begin{array}{c}0.0408^{a} \\
-0.0922^{2}\end{array}$ & $\begin{array}{l}-0.001 \\
0.066^{\mathrm{a}}\end{array}$ & $\begin{array}{l}0.107 \\
0.414 a^{2}\end{array}$ & $\begin{array}{l}0.037 \\
0.4322^{a}\end{array}$ & $\begin{array}{l}0.0 .977 \\
0.520^{2}\end{array}$ & $\begin{array}{l}-0.04442 \\
0.422^{2}\end{array}$ & $\begin{array}{l}0.022 \\
0.384 a\end{array}$ & $\begin{array}{l}-0.0277 \\
0.7699\end{array}$ & $\begin{array}{c}0.4 .44^{a} \\
-0.721\end{array}$ & $\begin{array}{l}0.09977^{a} \\
-0.0889 a\end{array}$ & $\begin{array}{l}0.9190 \\
0.215\end{array}$ & $\begin{array}{l}0.111 \\
0.171\end{array}$ & 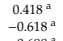 & 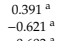 & $\begin{array}{l}0.1469 \\
0.3099\end{array}$ & $\begin{array}{c}0.1182 \\
-0.519 \mathrm{as}^{2}\end{array}$ & $\begin{array}{c}1 \\
-0.406 \mathrm{a}\end{array}$ & & & & & & & & & & & & & & & \\
\hline $\begin{array}{l}\text { LL } \\
\text { LW }\end{array}$ & $\begin{array}{l}-0.884^{a} \\
-0.061^{2} \\
-0.6 a^{2}\end{array}$ & 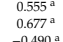 & 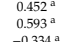 & $\begin{array}{c}0.463^{2} \\
0.5535^{2}\end{array}$ & 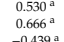 & $\begin{array}{l}0.0432^{2} \\
0.467^{2}\end{array}$ & $\begin{array}{l}0.230^{9} \\
0.300^{2}\end{array}$ & $\begin{array}{l}0.0576^{2} \\
0.0455^{2}\end{array}$ & 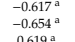 & $\begin{array}{l}-0.455^{2} \\
-0.9388^{2} \\
-0.75\end{array}$ & $\begin{array}{l}0.115 \\
0.294 b^{\circ} \\
0.24\end{array}$ & 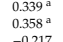 & 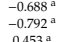 & $\begin{array}{l}-0.063^{\circ} \\
-0.0973^{a}\end{array}$ & 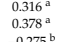 & $\begin{array}{l}-0.445^{2} \\
-0.0566^{2}\end{array}$ & $\begin{array}{l}-0.0638^{2} \\
-0.0322^{2}\end{array}$ & 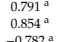 & $\begin{array}{c}0.122^{2} \\
0.8252^{2}\end{array}$ & & & & & & & & & & & & & \\
\hline $\begin{array}{l}\mathrm{An} \\
\mathrm{pH} \\
\mathrm{FW}\end{array}$ & $\begin{array}{c}0.0 .84^{a} \\
-0877^{2}\end{array}$ & $\begin{array}{l}-0.479 \mathrm{a} \\
-0.667 \\
0.678\end{array}$ & $\begin{array}{l}-0.588^{-2} \\
0 \\
0.600^{2}\end{array}$ & $\begin{array}{l}-0.546^{a} \\
-0.581^{2}\end{array}$ & 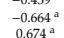 & 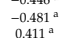 & $\begin{array}{l}-0.2428 \mathrm{~b} \\
-0.2484 \\
0.221\end{array}$ & $\begin{array}{l}-0.0500^{\circ} \\
0.0740^{2}\end{array}$ & $\begin{array}{l}0.667^{\mathrm{a}} \\
-0.618\end{array}$ & $\begin{array}{c}0.05177^{a} \\
-0.068^{a}\end{array}$ & $\begin{array}{l}-0.013 \\
-0.213 \\
0.2215\end{array}$ & $\begin{array}{l}-0.231^{\mathrm{b}} \\
0_{3013}\end{array}$ & 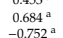 & 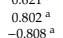 & 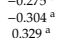 & $\begin{array}{l}0.5500^{0.550} \\
-0.056 a^{2}\end{array}$ & $\begin{array}{l}0.500^{0.9} \\
-0.0931^{2}\end{array}$ & 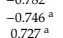 & $\begin{array}{l}-0.05174^{a} \\
-0.764 a^{2}\end{array}$ & $\begin{array}{l}-0.8355^{-1} \\
0.8585\end{array}$ & & & & & & & & & & & & \\
\hline 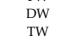 & $\begin{array}{l}-0.866^{\mathrm{a}} \\
-0.8 .84^{\mathrm{a}}\end{array}$ & $\begin{array}{l}0.673^{\mathrm{a}} \\
0.770^{2}\end{array}$ & $\begin{array}{l}0.576^{\mathrm{a}} \\
0.060^{2}\end{array}$ & $\begin{array}{l}0.566^{\mathrm{a}} \\
0.0586^{2}\end{array}$ & $\begin{array}{l}0.066^{\mathrm{a}} \\
0.088 \mathrm{a}^{2}\end{array}$ & $\begin{array}{l}0.400^{a} \\
0.0432^{2}\end{array}$ & $\begin{array}{l}0.220 \\
0.2511^{b}\end{array}$ & $\begin{array}{l}0.465^{\mathrm{a}} \\
0.0949 \mathrm{a}^{2}\end{array}$ & $\begin{array}{l}-0.019^{a} \\
-0.66^{a}\end{array}$ & $\begin{array}{l}-0.866^{\mathrm{a}} \\
-0.0817^{2}\end{array}$ & $\begin{array}{l}0.217 \\
0.237 b^{6}\end{array}$ & $\begin{array}{l}0.283 \mathrm{~b}^{\mathrm{b}} \\
0.311^{\mathrm{a}}\end{array}$ & $\begin{array}{l}-0.748^{\mathrm{a}} \\
-0.0740^{2}\end{array}$ & $\begin{array}{l}-0.821^{a} \\
-0.0281^{2}\end{array}$ & $\begin{array}{l}0.324^{2} \\
0.347^{2}\end{array}$ & $\begin{array}{l}-0.0499^{a} \\
-0.0495\end{array}$ & $\begin{array}{l}-0.401^{a} \\
-0.0934^{2}\end{array}$ & $\begin{array}{l}0.722^{2} \\
0.74 a^{a}\end{array}$ & $\begin{array}{l}0.743^{\mathrm{a}} \\
0.761 \mathrm{a}^{2}\end{array}$ & $\begin{array}{l}0.877^{\mathrm{a}} \\
0.855 a^{a}\end{array}$ & 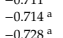 & $\begin{array}{l}-1.054^{a} \\
-0.0564^{2}\end{array}$ & $\begin{array}{l}0.999 \mathrm{asa}^{2} \\
0.09 \mathrm{a}^{\mathrm{a}}\end{array}$ & & & & & & & & & \\
\hline 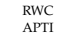 & $\begin{array}{l}0.048 \\
0.574^{\mathrm{a}}\end{array}$ & $\begin{array}{l}-0.135 \\
-0.423^{2}\end{array}$ & $\begin{array}{l}-0.044 \\
-0.270^{\mathrm{b}}\end{array}$ & $\begin{array}{l}-0.062 \\
-0.284 \mathrm{~b}\end{array}$ & $\begin{array}{l}-0.0999 \\
-0.371^{\mathrm{a}}\end{array}$ & $\begin{array}{l}-0.095 \\
-0.337^{a}\end{array}$ & $\begin{array}{l}-0.177 \\
-0.324^{a}\end{array}$ & $\begin{array}{l}-0.071 \\
-0.432^{\mathrm{a}}\end{array}$ & $\begin{array}{l}0.158 \\
0.529^{\mathrm{a}}\end{array}$ & $\begin{array}{c}0.151 \\
0.6111^{\mathrm{a}}\end{array}$ & $\begin{array}{l}-0.064 \\
-0.1633\end{array}$ & $\begin{array}{c}0.0 .08 \\
-0.111\end{array}$ & $\begin{array}{c}0.099 \\
0.433^{\mathrm{a}}\end{array}$ & 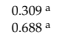 & $\begin{array}{l}-0.065 \\
-0.1177\end{array}$ & $\begin{array}{l}-0.077 \\
0.226^{\mathrm{b}}\end{array}$ & $\begin{array}{l}0.1 .122 \\
0.382^{2}\end{array}$ & $\begin{array}{c}-0.051 \\
-0.0528^{\mathrm{a}}\end{array}$ & $\begin{array}{c}-0.144 \\
-0.0488^{a}\end{array}$ & $\begin{array}{c}-0.073 \\
-0.553^{\mathrm{a}}\end{array}$ & $\begin{array}{l}0.053 \\
0.593^{\circ}\end{array}$ & $\begin{array}{l}0.071 \\
0.604 a^{2}\end{array}$ & $\begin{array}{c}-0.0700 \\
-0.0594^{2}\end{array}$ & $\begin{array}{c}-0.118 \\
-0.0311^{2}\end{array}$ & $\begin{array}{c}-0.103 \\
-0.022^{\mathrm{a}}\end{array}$ & $\begin{array}{c}1 \\
0.796^{\mathrm{a}}\end{array}$ & & & & & & \\
\hline $\begin{array}{l}\text { Sol } \\
\text { APX }\end{array}$ & $\begin{array}{l}0.0552^{\mathrm{a}} \\
0.999 \mathrm{a}^{2}\end{array}$ & $\begin{array}{l}-0.6022^{\mathrm{a}} \\
-0.647^{2}\end{array}$ & $\begin{array}{l}-0.5177^{\mathrm{a}} \\
-0.54 \mathrm{a}^{2}\end{array}$ & $\begin{array}{l}-0.5333^{\mathrm{a}} \\
-0.561^{2}\end{array}$ & $\begin{array}{l}-0.599^{\mathrm{a}} \\
-0.028^{\mathrm{a}}\end{array}$ & $\begin{array}{l}-0.399^{\mathrm{a}} \\
-0.4147^{2}\end{array}$ & $\begin{array}{l}-0.209 \\
-0.284^{\mathrm{b}}\end{array}$ & $\begin{array}{l}-0.555^{\mathrm{a}} \\
-0.063^{\mathrm{a}}\end{array}$ & $\begin{array}{l}0.6 .60^{\mathrm{a}} \\
0.0964^{\mathrm{a}}\end{array}$ & $\begin{array}{l}0.0596^{\mathrm{a}} \\
0.978 \mathrm{a}^{2}\end{array}$ & $\begin{array}{l}-0.0 \\
-0 .\end{array}$ & $\begin{array}{l}-0.250^{\mathrm{b}} \\
-0.030 \mathrm{~g}^{2}\end{array}$ & $\begin{array}{l}0.8 \\
0.8\end{array}$ & $\begin{array}{l}\begin{array}{l}0.745^{a} \\
0.712^{2}\end{array} \\
0\end{array}$ & $\begin{array}{l}-0.0 .06^{\mathrm{a}} \\
-0.036 \mathrm{~s}^{2}\end{array}$ & $\begin{array}{l}0_{0.494 a^{a}} \\
0.54 a^{2}\end{array}$ & $\begin{array}{l}0 . \\
0 . \\
0 .\end{array}$ & & & $\begin{array}{l}-0.0 \\
-0 . \\
-0.0\end{array}$ & $\begin{array}{l}0.799^{a} \\
0.762^{a 2}\end{array}$ & $\begin{array}{l}0.0877^{a} \\
0.442^{a}\end{array}$ & $-0.884^{a}$ & $\begin{array}{l}-0.039 \mathrm{~s}^{2} \\
-0.875^{\mathrm{a}}\end{array}$ & $\begin{array}{l}-0.041^{a} \\
-0.8877^{2}\end{array}$ & $\begin{array}{l}0.0 .035 \\
0.079\end{array}$ & $\begin{array}{l}0.0569^{\mathrm{a}} \\
0.577 \mathrm{a}^{2}\end{array}$ & ${ }_{0.962^{\mathrm{a}}}^{1}$ & & & & \\
\hline & 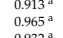 & $-0.614^{2}$ & $\begin{array}{l}-0.568 \mathrm{a} \\
-0.5050 \mathrm{a}\end{array}$ & $\begin{array}{l}-0.566^{2} \\
-0.490^{2}\end{array}$ & $\begin{array}{l}-0.655^{a} \\
-0.557\end{array}$ & & $\begin{array}{l}-0.251 \mathrm{~b} \\
-0.262^{\mathrm{b}}\end{array}$ & 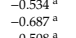 & $\begin{array}{l}0.6566^{\mathrm{a}} \\
0.627^{\mathrm{a}}\end{array}$ & & & & & & & & & & & & & & & & 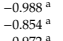 & $\begin{array}{l}0.0 .098 \\
0.082\end{array}$ & $\begin{array}{l}0.0260^{a} \\
0.5572\end{array}$ & $\begin{array}{l}0.9611^{a} \\
0.9311^{a}\end{array}$ & $\begin{array}{l}0.923^{2} \\
0.967^{a}\end{array}$ & $0.884^{\mathrm{a}}$ & & \\
\hline & & & & & & & & & & & & & & & & & & & & & & & & & & & & & $0.943^{\mathrm{a}}$ & & & \\
\hline
\end{tabular}
a. Correlation is significant at the 0.01 level; b. Correlation is significant at the 0.05 level. Chl. a, Chlorophyll $a$, Chl. b; Chlorophyll b; CTDS, Carotenoids; T. Chl. Total Chlorophyll; NPR, Net Suspended Particulate Matter, $S L A$, Specific leaf area, $L L$, leaf length, $L W$, Leaf width, $A A$, Ascorbic acid, $F W$, Fresh weight, $D W$, Dry weight, $T W$, Turgid weight, $R W C$, Relative water content, $A P T I$, Air pollution tolerance index, SOD, Superoxidase dismutase, $A P X$, Ascorbate peroxidase, $P O D$, Peroxidase, MDA, Malondialdehyde. 
The Analysis of variance (ANOVA) results exhibited a significant $(P<0.001)$ decrease in various parameters such as $\mathrm{pH}, \mathrm{FW}, \mathrm{DW}$ and TW of $P$. dulce at three different sites, whereas AA, and RWC, and APTI showed an increasing trend with an increase in the FA stress. Among the four parameters of APTI, AA content ( $\mathrm{mg} \mathrm{g}^{-1}$ fresh wt.) and RWC were found to increase with FA stress (Figure 3a). Being an antioxidant, AA counters the impact of air pollution on vegetation. Air pollution tolerance in plants is attributed to AA. Occurrence of higher AA content in leaves under water stress conditions might be an approach for protecting membranes of the thylakoid from oxidative destruction [1]. Several investigators have reported analogous results on AA content of leaves $[68,69]$. Similarly, higher $\mathrm{pH}$ in plant leaf extracts may lead to pollution tolerance in plants [1]. Leaf relative water content is related to protoplasmic permeability; consequently, plants with higher RWC are conceivably more tolerant to air pollutants. Physiological balance under stressful environmental conditions is maintained by plants through higher values of leaf relative water content especially when rates of transpiration normally stay higher. RWC in plants is considered to be an indicator of drought resistance [70].

A

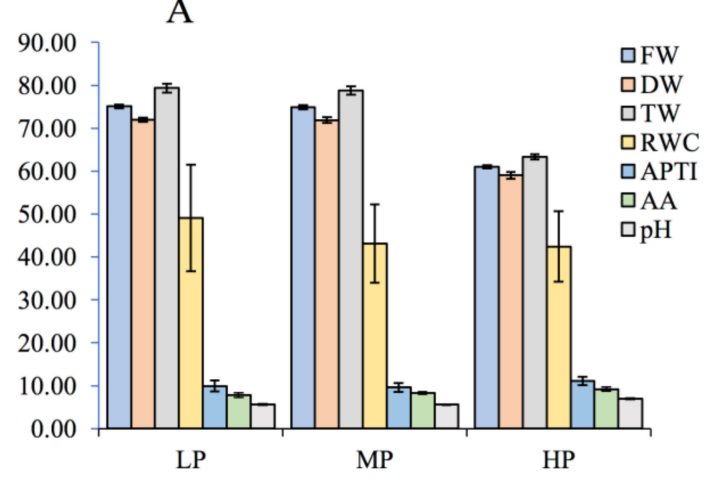

B

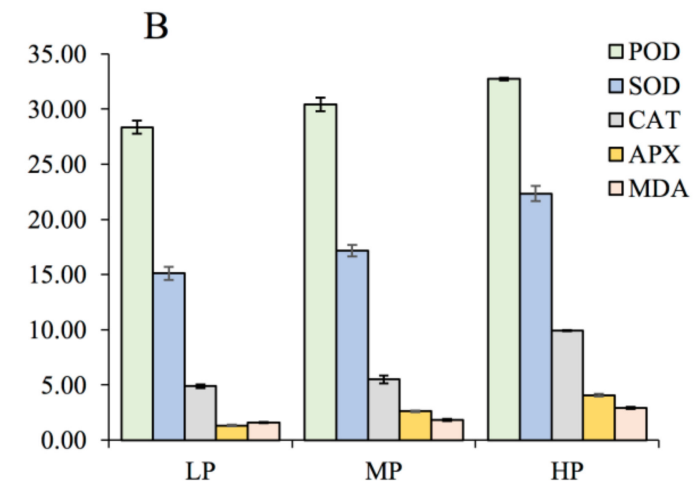

Figure 3. Site-specific variation in APTI of P. dulce (A) APTI and related parameters (B) Variation in the antioxidant enzymes activities of POD, SOD, CAT and APX (EU mg ${ }^{-1}$ protein) at three different sites and MDA content $\left(\mu \mathrm{g} \mathrm{g}^{-1} \mathrm{fw}\right)$. Data represents mean $\pm \mathrm{SD}(n=5)$.

The MDA content increased significantly from LPS to HPS sites representing an increment of $84.81 \%$ between the control and the maximum pollution site, as shown in Figure $3 \mathrm{~b}$. In contrast to the above parameters at HPS site, a remarkable increase was observed in antioxidant enzyme activities in the leaves of $P$. dulce, as compared to LPS. The minimum SOD activity of $15.11 \mathrm{U} \mathrm{mg}^{-1} \mathrm{FW}$ was perceived at LPS, which progressively increased to $17.15 \mathrm{U} \mathrm{mg}^{-1} \mathrm{FW}(13.5 \%)$ at MPS and reached a maximum of $22.34 \mathrm{U} \mathrm{mg}^{-1} \mathrm{FW}(47.85 \%)$ at HPS, while the activity of APX increased from $1.33 \mathrm{U}$ $\mathrm{mg}^{-1} \mathrm{FW}$ at LPS to $2.62 \mathrm{U} \mathrm{mg}^{-1} \mathrm{FW}(97 \%)$ at MPS and $4.06 \mathrm{U} \mathrm{mg}^{-1} \mathrm{FW}(207.58 \%)$ at HPS. Similarly, CAT activity also increased significantly from LPS to HPS, the minimum value of $4.89 \mu \mathrm{mol} \mathrm{min}{ }^{-1}$ observed at LPS increased to $5.51 \mu \mathrm{mol} \mathrm{min}{ }^{-1}(12.67 \%)$ at MPS and finally to $9.92 \mu \mathrm{mol} \mathrm{min}^{-1}(102.86 \%)$ at HPS. The POD activity enhanced from a minimum of $28.35 \mu \mathrm{mol} \mathrm{min}{ }^{-1}$ at LPS to a maximum of $32.72 \mu \mathrm{mol} \mathrm{min}-1$ at HPS showing an increment of $15.41 \%$ between LPS and HPS. ANOVA indicated significant $(P<0.001)$ increase between antioxidants at three sites, as shown in Table 2 . The activity of antioxidant enzymes often seems to be hooked to levels and types of stress but certain other factors like ecological conditions, duration of stress exposure and the degree of tolerance of the plant species also play a pivotal role in determination the antioxidant activity [70,71]. Various authors have reported their assessments on diverse facets of antioxidant enzyme playing their pivotal role in the biosynthesis of several important molecules, in the transport system and above all stress tolerance. An increase in the antioxidant enzymes like SOD, CAT, POD, and GR in roots, leaves and shoots of chickpea grown on fly ash, with increasing FA concentration in soil was reported by Pandey, et al. [17].

Transcriptional levels of several antioxidative enzymes, SOD, CAT, APX and POD in fly ash contaminated $P$. dulce plants was evaluated by qRT-PCR. Alleviated transcriptional expression profiles were observed in the case of SOD, POD, CAT and APX genes with an increase in pollution levels. 
Increased transcriptional levels of the genes in MPS and HPS plants were matched with those of growing at LPS levels. SOD, POD, CAT, and APX genes showed almost four-fold, increased gene expression level at MPS, while a 6 to 7-fold increase in the level of expression was observed at HPS (Figure 3b). Expression profiles of some stress related genes, viz. DREB and LEA were also studied. Compared to the LPS, increased expression levels were observed in P. dulce plants exposed to FA stress at both MPS and HPS. Since the genes have been observed to be induced under stressful conditions, the transcriptional levels were observed to be 3 to 5 -fold in the case of LEA and 4-5-fold in case of DREB (Figure 3b,c).

Various significant metabolic and physiological pathways operating in plants are the major sources of ROS. However, ROS accumulation under stressful environments could reassure cell disintegration, membrane damage, membrane lipid peroxidation, and can even lead to cell death $[72,73]$. With the passage of time plants have developed an extensive redox balancing mechanism based on the enzymatic and nonenzymatic antioxidant systems [74]. SOD being the first line of defense in the multifaceted enzymatic antioxidant defense systems, plays a significant role in converting $\mathrm{O}_{2}{ }^{*}$ to $\mathrm{O}_{2}$ and $\mathrm{H}_{2} \mathrm{O}_{2}$. Afterwards $\mathrm{H}_{2} \mathrm{O}_{2}$ is broken down by POD, and CAT to $\mathrm{H}_{2} \mathrm{O}[70,75,76]$. Several environmental perturbations in plants lead to higher antioxidant enzyme levels [72] correspondingly a substantial surge in CAT, POD, and SOD, activities were perceived in P. dulce plants after exposure to fly ash stress (Figure $3 b$ ).

Transcriptional expression levels were also detected in the case of an antioxidant defense system leading to stress tolerance in P. dulce plants. During the present study increased transcript expression of the CAT gene was observed under fly ash stress (Figure 4A,B). Similar reports of increased CAT expression were reported in the case of maize and Hordeum vulgare seedling under drought stress conditions [77]. Expression of antioxidant related genes is reported to be upregulated under abiotic stress conditions [78]. With several remarkable functions, LEA proteins are recounted to exist in diverse organisms that shield proteins from clumping due to desiccation or osmotic stresses prompted by different environmental conditions [79].

With respect to fly ash stress profuse transcript profiles of the LEA gene were perceived in P. dulce plants (Figure 4A,C). DREBs belong to an essential class of transcriptional factors that regulate several downstream stress responsive genes involved in stress tolerance. DREB transcriptional factors, such as DREB2 and DREB1 expression in several plants have been observed to be induced through dehydration and cold activated signalling pathways [80].

From earlier experiments it was publicized that the expression of AtDREBI occurs in response to cold stress but not due to drought and salinity stress [81]. Correspondingly, transcriptional expression of DREB2A and DREB2B was observed to be induced under high salt and osmotic stress rather than cold stress [81]. Abiotic stresses like salt, cold and drought induce transcriptional expression of PgDREB2A gene in Pennisetum glaucum [82]. Analogous expression profiles were detected in the case of the DREB gene expressed in P. dulce under fly ash stress, thus demonstrating its potential role in stress tolerance (Figure 4C). 


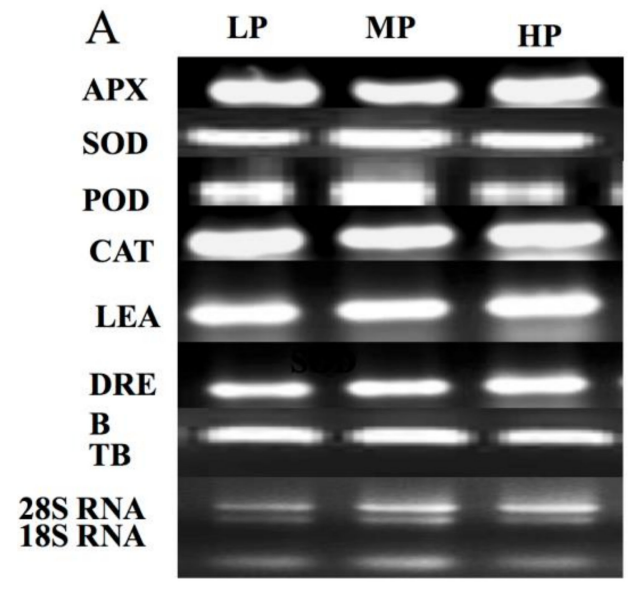

Low molecular weight RNA

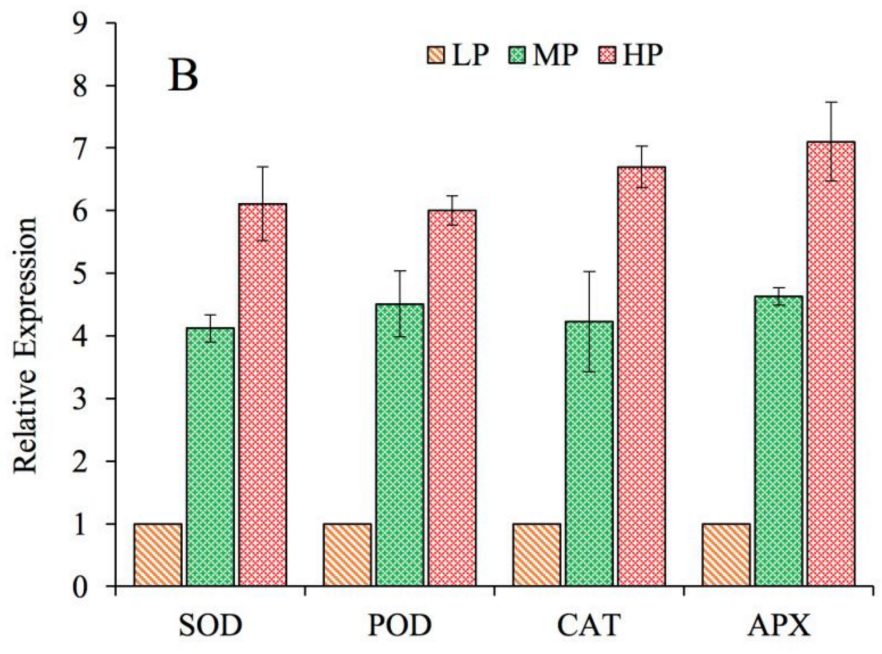

웅 DREB 농

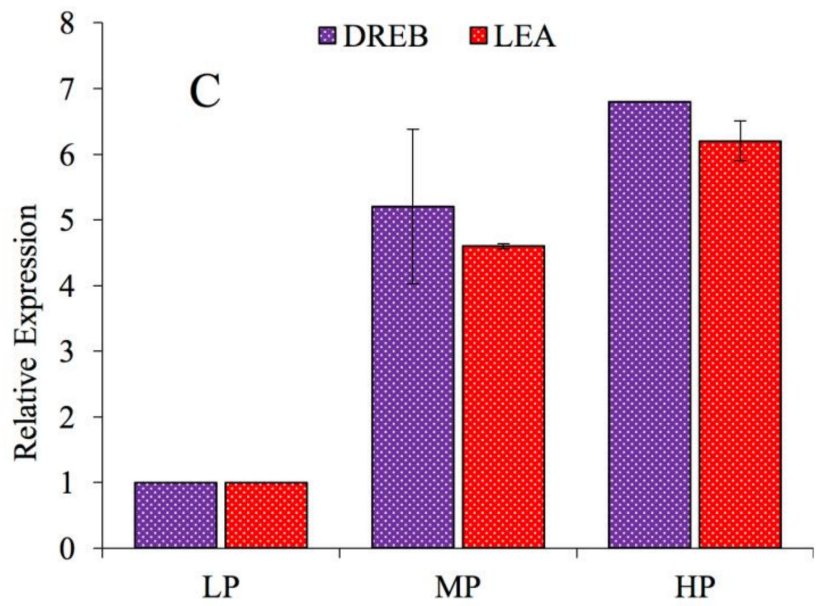

Figure 4. Transcriptional expression of antioxidant and stress related genes in P. dulce under fly ash stress. (A) Semi quantitative PCR showing expression. (B\&C) Relative gene expression of antioxidant and stress related genes through Real time PCR

\section{Conclusions}

Significant changes take place in various foliar, morphological, biochemical parameters, leaf attributes and antioxidant enzymes of $P$. dulce grown at different sites around a dumping site of Badarpur thermal power plant of the NCR of Delhi. However, despite all of these changes the APTI value of the plant species at MPS and HPS was greater, as compared to LPS, and the plants were flourishing very well at the polluted sites. It may, therefore, be concluded that $P$. dulce is a resistant plant species resistant to FA pollution. Hence, this species may be used for remediation of FA dumps and also used as the biomarker of /and for mitigation of FA pollution around thermal power plants. Further, plantation of this tree species would help in greening urban environments and for pollution control.

Author Contributions: Conceptualization, S.U.Q., V.R., W.A.S., M. and P.A. (Parvaiz Ahmad); Methodology, S.U.Q., V.R.; Software, E.F.A.A. and A.H.; Validation, M., P.A. (Pravej Alam) and P.A. (Parvaiz Ahmad); Formal analysis, W.A.S.; Investigation, S.U.Q.; Resources, W.A.S.; Data curation, E.F.A.A.; Writing-Original draft preparation, S.U.Q., V.R. and A.H. (Parvaiz Ahmad); Writing-Review and editing, V.R. and P.A. (Parvaiz Ahmad); Visualization, W.A.S. and M.; Supervision, W.A.S. and M.; Rroject administration, W.A.S; Funding acquisition, E.F.A.A., A.H., P.A. (Pravej Alam) and P.A. (Parvaiz Ahmad)

Acknowledgments: The authors would like to extend their sincere appreciation to the Researchers Supporting Project Number (RSP-2019/116), King Saud University, Riyadh, Saudi Arabia.

Conflicts of Interest: Authors declare that no conflict of interest exists. 


\section{References}

1. Pandey, A.K.; Pandey, M.; Mishra, A.; Tiwary, S.M.; Tripathi, B.D. Air pollution tolerance index and anticipated performance index of some plant species for development of urban forest. Urban For. Urban Green. 2015, 14, 866-871. [CrossRef]

2. Haynes, R. Reclamation and revegetation of fly ash disposal sites-Challenges and research needs. J. Environ. Manag. 2009, 90, 43-53. [CrossRef] [PubMed]

3. George, J.; Masto, R.E.; Ram, L.C.; Das, T.B.; Rout, T.K.; Mohan, M. Human exposure risks for metals in soil near a coal-fired power-generating plant. Arch. Environ. Contam. Toxicol. 2015, 68, 451-461. [CrossRef] [PubMed]

4. Pandey, V.C.; Singh, J.S.; Singh, R.P.; Singh, N.; Yunus, M. Arsenic hazards in coal fly ash and its fate in Indian scenario. Resour. Conserv. Recycl. 2011, 55, 819-835. [CrossRef]

5. Gupta, M.; Iqbal, M. Ontogenetic histological changes in the wood of mango (Mangifera indica L. cv Deshi) exposed to coal-smoke pollution. Environ. Exp. Bot. 2005, 54, 248-255. [CrossRef]

6. Pandey, V.C.; Prakash, P.; Bajpai, O.; Kumar, A.; Singh, N. Phytodiversity on fly ash deposits: Evaluation of naturally colonized species for sustainable phytorestoration. Environ. Sci. Pollut. Res. 2015, 22, $2776-2787$. [CrossRef] [PubMed]

7. Pandey, A.K.; Pandey, M.; Tripathi, B.D. Air Pollution Tolerance Index of climber plant species to develop Vertical Greenery Systems in a polluted tropical city. Landsc. Urban Plan. 2015, 144, 119-127. [CrossRef]

8. Ribeiro, J.; Silva, T.; Mendonça Filho, J.; Flores, D. Fly ash from coal combustion-An environmental source of organic compounds. Appl. Geochem. 2014, 44, 103-110. [CrossRef]

9. Pandey, V.C. Assisted phytoremediation of fly ash dumps through naturally colonized plants. Ecol. Eng. 2015, 82, 1-5. [CrossRef]

10. Pandey, V.C.; Singh, B. Rehabilitation of Coal Fly Ash Basins: Current Need to Use Ecological Engineering; Elsevier Academic Press: New York, NY, USA, 2012.

11. Jambhulkar, H.P.; Juwarkar, A.A. Assessment of bioaccumulation of heavy metals by different plant species grown on fly ash dump. Ecotoxicol. Environ. Saf. 2009, 72, 1122-1128. [CrossRef]

12. Juwarkar, A.A.; Jambhulkar, H.P. Restoration of fly ash dump through biological interventions. Environ. Monit. Assess. 2008, 139, 355-365. [CrossRef] [PubMed]

13. Ram, L.C.; Jha, S.K.; Tripathi, R.C.; Masto, R.E.; Selvi, V.A. Remediation of fly ash landfills through plantation. Remediation 2008, 18, 71-90. [CrossRef]

14. Qadir, S.U.; Raja, V.; Siddiqui, W.A. Morphological and biochemical changes in Azadirachta indica from coal combustion fly ash dumping site from a thermal power plant in Delhi, India. Ecotoxicol. Environ. Saf. 2016, 129, 320-328. [CrossRef] [PubMed]

15. Iqbal, M.; Jacob, M.; Mehta, S.; Mahmooduzzafar; Srivastava, P. Plant responses to particulate matters suspended in the air. In Environmental Hazards: Plants and People; CBS Publishers: New Delhi, India, 2000; pp. 80-112.

16. Goswami, S.; Das, S. Copper phytoremediation potential of Calandula officinalis L. and the role of antioxidant enzymes in metal tolerance. Ecotoxicol. Environ. Saf. 2016, 126, 211-218. [CrossRef] [PubMed]

17. Pandey, V.C.; Singh, J.S.; Kumar, A.; Tewari, D. Accumulation of heavy metals by chickpea grown in fly ash treated soil: Effect on antioxidants. CLEAN Soil Air Water 2010, 38, 1116-1123. [CrossRef]

18. Tauqeer, H.M.; Ali, S.; Rizwan, M.; Ali, Q.; Saeed, R.; Iftikhar, U.; Ahmad, R.; Farid, M.; Abbasi, G.H. Phytoremediation of heavy metals by Alternanthera bettzickiana: Growth and physiological response. Ecotoxicol. Environ. Saf. 2016, 126, 138-146. [CrossRef]

19. Sharma, P.; Jha, A.B.; Dubey, R.S.; Pessarakli, M. Reactive oxygen species, oxidative damage, and antioxidative defense mechanism in plants under stressful conditions. J. Bot. 2012, 2012, 1-26. [CrossRef]

20. Iqbal, M.; Abdin, M.Z.; Mahmooduzzafar; Yunus, M.; Agrawal, M. Resistance mechanisms in plants against air pollution. In Plant Response to Air Pollution; Yunus, M., Iqbal, M., Eds.; John Willey \& Sons: Chichester, UK, 1996; pp. 195-240.

21. Ali, I.; Liu, B.; Farooq, M.A.; Islam, F.; Azizullah, A.; Yu, C.; Su, W.; Gan, Y. Toxicological effects of bisphenol A on growth and antioxidant defense system in Oryza sativa as revealed by ultrastructure analysis. Ecotoxicol. Environ. Saf. 2016, 124, 277-284. [CrossRef] 
22. Pandey, V.C.; Singh, K.; Singh, R.P.; Singh, B. Naturally growing Saccharum munja L. on the fly ash lagoons: A potential ecological engineer for the revegetation and stabilization. Ecol. Eng. 2012, 40, 95-99. [CrossRef]

23. Kumari, A.; Pandey, V.C.; Rai, U.N. Feasibility of fern Thelypteris dentata for revegetation of coal fly ash landfills. J. Geochem. Explor. 2013, 128, 147-152. [CrossRef]

24. Pandey, V.C.; Bajpai, O.; Singh, N. Plant regeneration potential in fly ash ecosystem. Urban For. Urban Green. 2016, 15, 40-44. [CrossRef]

25. Chaturvedi, R.; Prasad, S.; Rana, S.; Obaidullah, S.; Pandey, V.; Singh, H. Effect of dust load on the leaf attributes of the tree species growing along the roadside. Environ. Monit. Assess. 2013, 185, 383-391. [CrossRef] [PubMed]

26. Lukaszkiwicz, J. Determining the age of alley trees with the dbh-height-based multi-factoral model. In Annals of Warsaw University of Life Sciences-SGGW; Horticulture and Landscape Architecture: West Lafayette, IN, USA, 2010; pp. 53-60.

27. Ghouse, A.; Yunus, M. Preparation of epidermal peels from leaves of gymnosperms by treatment with hot, 60 per cent $\mathrm{HNO}_{3}$. Stain Technol. 1972, 47, 322. [CrossRef] [PubMed]

28. Salisbury, E.J.I. On the causes and ecological significance of stomatal frequency, with special reference to the woodland flora. Philos. Trans. R. Soc. Lond. Ser. B Contain. Pap. Biol. Character 1928, 216, 1-65. [CrossRef]

29. Karcz, J.; Bernas, T.; Nowak, A.; Talik, E.; Woznica, A. Application of lyophilization to prepare the nitrifying bacterial biofilm for imaging with scanning electron microscopy. Scanning 2012, 34, 26-36. [CrossRef] [PubMed]

30. Hiscox, J.D.; Israelstam, G.F. A method for the extraction of chlorophyll from leaf tissue without maceration. Can. J. Bot. 1979, 57, 1332-1334. [CrossRef]

31. Duxbury, A.C.; Yentsch, C.S. Plankton Pigment Nomographs. J. Mar. Biol. 1956, 16, 145-150.

32. Maclachlan, S.; Zalik, S. Plastid structure, chlorophyll concentration and free amino acid composition of a chlorophyll mutant of barley. Can. J. Bot. 1963, 41, 1053-1062. [CrossRef]

33. Klepper, L.; Flesher, D.; Hageman, R.H. Generation of Reduced Nicotinamide Adenine Dinucleotide for Nitrate Reduction in Green Leaves. Plant Physiol. 1971, 48, 580-590. [CrossRef]

34. Grover, H.; Nair, T.; Abrol, Y. Nitrogen metabolism of the upper three leaf blades of wheat at different soil nitrogen levels: I. Nitrate reductase activity and content of various nitrogenous constituents. Physiol. Plant. 1978, 42, 287-292. [CrossRef]

35. Evans, H.J.; Nason, A. Pyridine Nucleotide-Nitrate Reductase from Extracts of Higher Plants. Plant Physiol. 1953, 28, 233-254. [CrossRef] [PubMed]

36. Lindner, R. Rapid analytical methods for some of the more common inorganic constituents of plant tissues. Plant Physiol. 1944, 19, 76. [CrossRef] [PubMed]

37. Dey, P.M. Carbohydrates. In Methods in Plant Biochemistry; Accademic Press: London, UK, 1990; Volume 2, pp. 189-218. [CrossRef]

38. Chesnin, L.; Yien, C. Turbidimetric determination of available sulfates 1. Soil Sci. Soc. Am. J. 1951, 15, 149-151. [CrossRef]

39. Bates, L.S.; Waldren, R.P.; Teare, I.D. Rapid determination of free proline for water-stress studies. Plant Soil 1973, 39, 205-207. [CrossRef]

40. Bradford, M. A Rapid and Sensitive Method for the Quantitation of Microgram Quantities of Protein Utilizing the Principle of Protein-Dye Binding. Anal. Biochem. 1976, 72, 248-254. [CrossRef]

41. Keller, T.; Schwager, H. Air pollution and ascorbic acid. Eur. J. For. Pathol. 1977, 7, 338-350. [CrossRef]

42. Qadir, S.U.; Siddiqui, W.A. Effect of fly ash on some biochemical parameters of selected plants growing at dumping site of badarpur thermal power plant in delhi. Int. J. Res. Appl. Nat. Soc. Sci. 2014, 2, 7-14.

43. Singh, S.K.; Rao, D.N.; Agrawal, M.; Pandey, J.; Naryan, D. Air pollution tolerance index of plants. J. Environ. Manag. 1991, 32, 45-55. [CrossRef]

44. Heath, R.L.; Packer, L. Photoperoxidation in isolated chloroplasts. Arch. Biochem. Biophys. 1968, 125, $189-198$. [CrossRef]

45. Nakano, Y.; Asada, K. Hydrogen peroxide is scavenged by ascorbate-specific peroxidase in spinach chloroplasts. Plant Cell Physiol. 1981, 22, 867-880.

46. Aebi, H. Catalase In Vitro. Methods Enzymol. 1984, 105, 121-126. [PubMed] 
47. Zhang, W.F.; Zhang, F.; Raziuddin, R.; Gong, H.J.; Yang, Z.M.; Lu, L.; Ye, Q.F.; Zhou, W.J. Effects of 5-Aminolevulinic Acid on Oilseed Rape Seedling Growth under Herbicide Toxicity Stress. J. Plant Growth Regul. 2008, 27, 159-169. [CrossRef]

48. Zhou, W.; Leul, M. Uniconazole-induced alleviation of freezing injury in relation to changes in hormonal balance, enzyme activities and lipid peroxidation in winter rape. Plant Growth Regul. 1998, 26, 41-47. [CrossRef]

49. Liu, S.; Chen, C.; Chen, G.; Cao, B.; Chen, Q.; Lei, J. RNA-sequencing tag profiling of the placenta and pericarp of pungent pepper provides robust candidates contributing to capsaicinoid biosynthesis. Plant Cell Tissue Organ Culture 2012, 110, 111-121. [CrossRef]

50. Livak, K.J.; Schmittgen, T.D. Analysis of Relative Gene Expression Data Using Real-Time Quantitative PCR and the 2- $\Delta \Delta \mathrm{CT}$ Method. Methods 2001, 25, 402-408. [CrossRef]

51. Iqbal, M.; Bano, R.; Wali, B. Plant Growth Responses to Air Pollution. Plant Biodiversity, Microbial Interaction and Environmental Biology; Avishkar Publishers: Jaipur, India, 2005; pp. 166-188.

52. Wali, B.; Iqbal, M.; Mahmooduzzafar. Anatomical and functional responses of Calendula officinalis L. to $\mathrm{SO}_{2}$ stress as observed at different stages of plant development. Flora Morphol. Distrib. Funct. Ecol. Plants 2007, 202, 268-280. [CrossRef]

53. Iqbal, M.; Mahmooduzzafar; Nighat, F.; Khan, P.R. Photosynthetic, metabolic and growth responses of Triumfetta rhomboideato coal-smoke pollution at different stages of plant ontogeny. J. Plant Interact. 2010, 5, 11-19. [CrossRef]

54. Ots, K.; Indriksons, A.; Varnagiryte-Kabasinskiene, I.; Mandre, M.; Kuznetsova, T.; Klõšeiko, J.; Tilk, M.; Kõresaar, K.; Lukjanova, A.; Kikamägi, K. Changes in the canopies of Pinus sylvestris and Picea abies under alkaline dust impact in the industrial region of Northeast Estonia. For. Ecol. Manag. 2011, 262, 82-87. [CrossRef]

55. Saha, D.C.; Padhy, P.K. Effects of stone crushing industry on Shorea robusta and Madhuca indica foliage in Lalpahari forest. Atmos. Pollut. Res. 2011, 2, 463-476. [CrossRef]

56. Tiwari, S.; Agrawal, M.; Marshall, F. Evaluation of ambient air pollution impact on carrot plants at a sub urban site using open top chambers. Environ. Monit. Assess. 2006, 119, 15-30. [CrossRef]

57. Wagh, N.; Shukla, P.V.; Tambe, S.B.; Ingle, S. Biological monitoring of roadside plants exposed to vehicular pollution in Jalgaon city. J. Environ. Biol. 2006, 37, 419-421.

58. Verma, A.; Singh, S.N. Biochemical and Ultrastructural Changes in Plant Foliage Exposed to Auto-Pollution. Environ. Monit. Assess. 2006, 120, 585-602. [CrossRef] [PubMed]

59. Joshi, P.; Swami, A. Air pollution induced changes in the photosynthetic pigments of selected plant species. J. Environ. Biol. 2009, 30, 295-298.

60. Joshi, N.; Chauhan, A.; Joshi, P.C. Impact of industrial air pollutants on some biochemical parameters and yield in wheat and mustard plants. Environmentalist 2009, 29, 398-404. [CrossRef]

61. Bashir, H.; Ibrahim, M.M.; Bagheri, R.; Ahmad, J.; Arif, I.A.; Baig, M.A.; Qureshi, M.I. Influence of sulfur and cadmium on antioxidants, phytochelatins and growth in Indian mustard. AoB Plants 2015, 7. [CrossRef]

62. Iqbal, M.; Jura-Morawiec, J.; WŁoch, W.; Mahmooduzzafar. Foliar characteristics, cambial activity and wood formation in Azadirachta indica A. Juss. as affected by coal-smoke pollution. Flora-Morphol. Distrib. Funct. Ecol. Plants 2010, 205, 61-71. [CrossRef]

63. Grantz, D.; Garner, J.; Johnson, D. Ecological effects of particulate matter. Environ. Int. 2003, 29, $213-239$. [CrossRef]

64. Sharma, A.P.; Tripathi, B.D. Biochemical responses in tree foliage exposed to coal-fired power plant emission in seasonally dry tropical environment. Environ. Monit. Assess. 2008, 158, 197-212. [CrossRef]

65. Kumar, A.; Vajpayee, P.; Ali, M.B.; Tripathi, R.D.; Singh, N.; Rai, U.N.; Singh, S.N. Biochemical Responses of Cassia siamea Lamk. Grown on Coal Combustion Residue (Fly-ash). Bull. Environ. Contam. Toxicol. 2002, 68, 675-683. [CrossRef]

66. Hayat, S.; Hayat, Q.; Alyemeni, M.N.; Wani, A.S.; Pichtel, J.; Ahmad, A. Role of proline under changing environments. Plant Signal. Behav. 2012, 7, 1456-1466. [CrossRef]

67. Tripathi, A.; Gautam, M. Biochemical parameters of plants as indicators of air pollution. J. Environ. Biol. 2007, 28, 127. [PubMed]

68. Krishnaveni, M. Air pollution tolerance index and antioxidant activity of Parthenium hysterophorus. J. Pharm. Res. 2013, 7, 296-298. [CrossRef] 
69. Kaur, R.; Nayyar, H. Ascorbic acid: A potent defender against environmental stresses. In Oxidative Damage to Plants; Elsevier Academic Press: New York, NY, USA, 2014; pp. 235-287.

70. Aref, I.M.; Khan, P.R.; Khan, S.; El-Atta, H.; Ahmed, A.I.; Iqbal, M. Modulation of antioxidant enzymes in Juniperus procera needles in relation to habitat environment and dieback incidence. Trees 2016, 30, 1669-1681. [CrossRef]

71. Zouari, M.; Ahmed, C.B.; Zorrig, W.; Elloumi, N.; Rabhi, M.; Delmail, D.; Rouina, B.B.; Labrousse, P.; Abdallah, F.B. Exogenous proline mediates alleviation of cadmium stress by promoting photosynthetic activity, water status and antioxidative enzymes activities of young date palm (Phoenix dactylifera L.). Ecotoxicol. Environ. Saf. 2016, 128, 100-108. [CrossRef]

72. Raja, V.; Majeed, U.; Kang, H.; Andrabi, K.I.; John, R. Abiotic stress: Interplay between ROS, hormones and MAPKs. Environ. Exp. Bot. 2017, 137, 142-157. [CrossRef]

73. Foyer, C.H.; Ruban, A.V.; Noctor, G. Viewing oxidative stress through the lens of oxidative signalling rather than damage. Biochem. J. 2017, 474, 877-883. [CrossRef]

74. Petrov, V.; Hille, J.; Mueller-Roeber, B.; Gechev, T.S. ROS-mediated abiotic stress-induced programmed cell death in plants. Front. Plant Sci. 2015, 6, 69. [CrossRef]

75. Hu, Z.; Fan, J.; Xie, Y.; Amombo, E.; Liu, A.; Gitau, M.M.; Khaldun, A.B.M.; Chen, L.; Fu, J. Comparative photosynthetic and metabolic analyses reveal mechanism of improved cold stress tolerance in bermudagrass by exogenous melatonin. Plant Physiol. Biochem. 2016, 100, 94-104. [CrossRef]

76. Jan, N.; Majeed, U.; Andrabi, K.I.; John, R. Cold stress modulates osmolytes and antioxidant system in Calendula officinalis. Acta Physiol. Plant. 2018, 40. [CrossRef]

77. Harb, A.; Awad, D.; Samarah, N. Gene expression and activity of antioxidant enzymes in barley (Hordeum vulgare L.) under controlled severe drought. J. Plant Interact. 2015, 10, 109-116. [CrossRef]

78. Teixeira, F.K.; Menezes-Benavente, L.; Galvão, V.C.; Margis, R.; Margis-Pinheiro, M. Rice ascorbate peroxidase gene family encodes functionally diverse isoforms localized in different subcellular compartments. Planta 2006, 224, 300. [CrossRef] [PubMed]

79. Hundertmark, M.; Hincha, D.K. LEA (Late Embryogenesis Abundant) proteins and their encoding genes in Arabidopsis thaliana. BMC Genom. 2008, 9, 118. [CrossRef] [PubMed]

80. Sakuma, Y.; Liu, Q.; Dubouzet, J.G.; Abe, H.; Shinozaki, K.; Yamaguchi-Shinozaki, K. DNA-binding specificity of the ERF/AP2 domain of Arabidopsis DREBs, transcription factors involved in dehydration-and cold-inducible gene expression. Biochem. Biophys. Res. Commun. 2002, 290, 998-1009. [CrossRef] [PubMed]

81. Nakashima, K.; Shinwari, Z.K.; Sakuma, Y.; Seki, M.; Miura, S.; Shinozaki, K.; Yamaguchi-Shinozaki, K. Organization and expression of two Arabidopsis DREB2 genes encoding DRE-binding proteins involved in dehydration-and high-salinity-responsive gene expression. Plant Mol. Biol. 2000, 42, 657-665. [CrossRef] [PubMed]

82. Gao, S.-Q.; Chen, M.; Xia, L.-Q.; Xiu, H.-J.; Xu, Z.-S.; Li, L.-C.; Zhao, C.-P.; Cheng, X.-G.; Ma, Y.-Z. A cotton (Gossypium hirsutum) DRE-binding transcription factor gene, GhDREB, confers enhanced tolerance to drought, high salt, and freezing stresses in transgenic wheat. Plant Cell Rep. 2009, 28, 301-311. [CrossRef]

(C) 2019 by the authors. Licensee MDPI, Basel, Switzerland. This article is an open access article distributed under the terms and conditions of the Creative Commons Attribution (CC BY) license (http://creativecommons.org/licenses/by/4.0/). 